NBER WORKING PAPER SERIES

\title{
WHY WORK MORE? THE IMPACT OF TAXES, AND CULTURE OF LEISURE ON LABOR SUPPLY IN EUROPE
}

\author{
Naci H. Mocan \\ Luiza Pogorelova \\ Working Paper 21297 \\ http://www.nber.org/papers/w21297
NATIONAL BUREAU OF ECONOMIC RESEARCH
1050 Massachusetts Avenue
Cambridge, MA 02138
June 2015

The views expressed herein are those of the authors and do not necessarily reflect the views of the National Bureau of Economic Research.

NBER working papers are circulated for discussion and comment purposes. They have not been peerreviewed or been subject to the review by the NBER Board of Directors that accompanies official NBER publications.

(C) 2015 by Naci H. Mocan and Luiza Pogorelova. All rights reserved. Short sections of text, not to exceed two paragraphs, may be quoted without explicit permission provided that full credit, including (C) notice, is given to the source. 
Why Work More? The Impact of Taxes, and Culture of Leisure on Labor Supply in Europe Naci H. Mocan and Luiza Pogorelova

NBER Working Paper No. 21297

June 2015

JEL No. H2,J22,J61,Z1

\begin{abstract}
$\underline{\text { ABSTRACT }}$
We use micro data from the European Social Survey to investigate the impact of "culture of leisure" and taxes on labor force participation and hours worked of second-generation immigrants who reside in 26 European countries. These individuals are born in Europe, and they have been exposed to institutional, legal and labor market structures of their countries, including the tax rates. Fathers of these individuals are first-generation immigrants who migrated from 81 different countries. We construct measures of "taste for leisure" in the country of origin of each immigrant father. We employ average and marginal taxes for each country of residence, and control for a large set of individual characteristics, in addition to attributes of the country of residence and country of ancestry. The results show that for women, both taxes and culture of leisure impact participation and hours worked. For men, taxes influence labor supply both at the intensive and the extensive margins, but culture of leisure has no impact.
\end{abstract}

Naci H. Mocan

Department of Economics

Louisiana State University

3039 BEC

Baton Rouge, LA 70803-6306

and NBER

mocan@1su.edu

Luiza Pogorelova

Department of Economics

Louisiana State University

Business Education Complex

Baton Rouge, LA 70803

lpogor1@1su.edu 
Why Work More?

The Impact of Taxes, and Culture of Leisure on Labor Supply in Europe

\section{Introduction}

There are substantial differences between people around the world regarding how many hours they work in the labor market. For example, in 2012, the average annual hours worked by American workers was 1,750. The average worker in Germany worked 17 percent fewer hours than an American worker in that year, and a French worker worked 15 percent less. A worker in Belgium spent about 9 percent less time at work in comparison to an American worker. Similar disparities are observed when hours per person is analyzed, instead of hours per worker. ${ }^{1}$ Annual hours worked per working age population (ages 15 to 64 ) are 10 percent lower in Germany, 19\% lower in France, and 17 percent lower in Belgium than in the U.S.

In an influential paper, Edward Prescott (2004) employed a growth model with a representative household and calibrated the model to show that the difference in hours worked between the United States and Europe in two points in time can be explained almost entirely by the differences in the tax rates on labor and consumption. A large literature that followed provided a number of nuanced extensions and modifications to Prescott's framework, regarding the preferred labor supply elasticities to calibrate such macro models, modifications to the model to incorporate the ability for the household to self-insure through asset accumulation, the role of productivity growth, and so on (e.g. Ljungqvist and Sargent 2006, Ohanian et al. 2008, Rogerson 2008, Olovsson 2009, Chetty et al. 2011, McDaniel

\footnotetext{
${ }^{1}$ This measure incorporates both the willingness to participate in the labor market (the decision on whether or not to work) and the decision on how many hours to work.
} 
2011). In a different framework, Algan and Cahuc (2005) showed that family labor supply attitudes were important in explaining the variation in the employment rates of different demographic groups in OECD countries.

The finding that taxes are a major factor in explaining cross-country differences in market work is important because it implies that reductions in taxes can generate significant increases in economic activity. Alternative, or at least complementary, hypotheses have been proposed to explain the differences in hours worked between Europe and the U.S. These include the importance of regulations and labor unions (Alesina, Glaeser and Sacerdote 2006), and the role of home production (Olovsson 2015). An important aspect of this discussion, and the key component of our paper, is the role of preferences for leisure. The assumption of identical preferences between countries, and in particular between Europeans and Americans has been questioned (Blanchard 2006). This point is also emphasized by Alesina, Glaeser and Sacerdote (2006) who suggested that an initial decline in market work might increase individuals' utility from leisure and this process can be amplified by a social multiplier (Glaeser, Sacerdote and Scheinkman 2003) if there exist complementarities in leisure - individuals' utility from leisure is enhanced when more people are consuming leisure.

The argument that Europeans have stronger taste for leisure than Americans (Blanchard 2004) is perhaps intuitive, and fits well with many people's pre-conceived image of longer vacations and shorter work weeks in most European countries. That image was brought to life in a Cadillac TV advertisement in the U.S., where the main character in the advertisement, an American middle-age upper-income male, first asks the question: "Why do we work so hard?" In answering his own question, he declares: 
"[In] Other countries, they work, they stroll home, they stop by the café, they take August off. Off! Why aren't you like that? Why aren't we like

that? Because we are crazy, driven, hard-working believers. That's why.

Those other countries think we are nuts. Whatever! ‘2

Although tastes for leisure can impact labor supply, no systematic analysis has been conducted on this subject. ${ }^{3}$ In this paper, we focus on European countries and investigate the impact of taxes and the culture of leisure on labor supply. Using a large micro data set consisting of individuals from 26 European countries we analyze people's labor supply decisions both at the extensive and the intensive margins. ${ }^{4}$ While there are significant differences between Americans and Europeans in hours worked, there are also substantial differences in market work between European countries. To demonstrate the extent of

\footnotetext{
${ }^{2}$ Cadillac commercial can be found at : http://www.ispot.tv/ad/7BkA/cadillac-elr-work-hard

${ }^{3}$ Standard empirical models of labor supply include a vector of worker attributes including racial and ethnic background, if available, in an effort to control for pre-market factors that can impact labor supply, but explicit adjustment to taste for leisure has not been done so far.
}

${ }^{4}$ The conjecture is that some countries have stronger preferences for leisure, and people in those countries would have worked fewer hours even if they faced lower marginal tax rates. On the face of it, this argument does not seem to explain the increasing wedge between labor supply of Americans and Europeans over the last three decades or so, because culture is not expected to change rapidly. Even though the goal of our paper is not to explain the divergence of hours worked between countries over time, we should still emphasize that cultural attributes are malleable, and they change in reaction to external factors. For example, Fernández (2013) shows that social attitudes towards women's work endogenously change over time. Alesina and Fuchs-Schündeln (2007) find that individual preferences are shaped by the political regime in which the individual lives. Giuliano and Spilimbergo (2014) show that individuals' political preferences and support for government redistribution are impacted by whether or not they grew up during recessionary periods. Giavazzi, Petkov and Schiantarelli (2014) show that while some cultural values evolve slowly, others change rapidly. Cannonier and Mocan (2012) find that women in Sierra Leone whose education is improved by an education reform are more likely to disapprove the cultural practice of female genital mutilation. Mocan (2013) finds that the intensity of vengeful feelings depends on the economic environment of the individual. 
variation between countries in hours worked, we use OECD data and calculate hours worked per population ages 15 to 64 in 2012, in a sample of European countries, which is displayed in Table 1. This measure contains two dimensions of market work: the fraction of the working age population that actually works and the number of hours of those who work. The entries in Table 1 are standardized to portray average hours worked in each country relative to the U.K. For example, hours worked per person in France, Germany and Greece are 19 percent, 10 percent, and 3 percent lower, respectively, than in the U.K. Swedes work 4 percent more than the working age population in the U.K. Importantly, as we will show later in the paper, there is also substantial variation in the effective marginal tax rates between European countries.

The critical issue for the purposes of our paper is how to measure the "taste for leisure," and how to identify its impact on market work. We focus on second-generation immigrants who reside in various European countries. These individuals are born in Europe, and being residents of different European countries, they have been exposed to institutional, legal and labor market structures of their countries, including the marginal tax rates on labor and consumption income. Their fathers had migrated from somewhere else in the world, and we know these fathers' countries of origin. We use immigrant father's country of birth to determine the ancestral roots, and assume that culture of leisure in father's country of origin is transmitted from the immigrant father to the offspring. We focus on the father, rather than the mother because most of the literature uses the birth place of the father to assign country of origin to second-generation immigrants (Alesina et al. 2015, Alesina and Giuliano 2011, Alesina and Giuliano 2010, Fernández and Fogli 2009, Card et al. 1998). By exploiting a separate data set that asks people around the world various questions to gauge their taste for 
leisure, we connect these second-generation immigrants in Europe to the culture of leisure in their father's country of origin.

We have data from about 7,000 individuals who live and work in 26 European countries. These individuals have ancestral origins in 81 different countries. Thus, we are able to identify the impact of taxes in the country of residence on hours worked, holding constant observable attributes of individuals, various attributes of the country in which they live, and attributes of their father's country of origin, including the taste for leisure in that country of origin. Similarly, we can identify the impact of culture of leisure on labor supply, holding constant all personal attributes and various characteristics of the country of residence, including the tax rates.

We find that both taxes and culture of leisure impact labor force participation and hours worked for women. For men, taxes influence labor supply both at the intensive and the extensive margin, but culture of leisure has no impact. The magnitude of the estimated effects indicates that while taxes on labor income are a significant determinant of aggregate hours worked, culture of leisure is important as well.

Our work is also related to a growing new literature that investigates the interplay between culture and economic outcomes. Some recent examples include Fernández and Fogli (2009) who investigate the impact of female labor force participation and fertility rates in the country of origin on work and fertility decisions of second-generation American women; Alesina and Giuliano (2011) who investigate the impact of family ties on political participation, labor force participation and trust. Luttmer and Singhal (2011) report that immigrants' redistributive preferences are impacted by the average preference in their country of birth. Ljunge (2014) analyzes the transmission of trust to immigrant children. 
Alesina et al. (2015) find that people who inherit strong family ties are less mobile and have lower wages and higher unemployment. A detailed description of this literature can be found in Alesina and Giuliano (2014) and Fernández (2011).

\section{Theoretical Framework}

To motivate the empirical model, we follow the framework of Prescott (2004) and consider a representative agent who is endowed with one unit of time that can be divided between labor and leisure. Preferences over consumption and leisure are represented by the utility function in Equation (1):

1) $U=\sum_{t=0}^{\infty} \beta^{t}\left(\log c_{t}+\gamma \log \left(1-h_{t}\right)\right)$

where $c_{t}$ stands for consumption and $h_{t}$ represents hours worked; implying that $\left(1-h_{t}\right)$ is the amount of leisure. The discount factor $\beta$ represents the degree of patience, where $0<\beta<1$. The parameter $\gamma$ is the value attached to leisure. The aggregate production function of the economy is that of Cobb-Douglas type, with an output elasticity of capital $\theta$, and elasticity of labor $(1-\theta)$. The production function converts labor $\left(h_{t}\right.$ in Equation 1$)$ and capital into output, which can be consumed or invested.

The budget constraint of the representative agent is:

2) $\left(1+\tau_{c}\right) c_{t}+\left(1+\tau_{x}\right) x_{t}=\left(1-\tau_{h}\right) w_{t} h_{t}+\left(1-\tau_{k}\right) r_{t} k_{t}+T_{t}$

where $\tau_{\mathrm{c}}$ is the consumption tax rate, $\tau_{\mathrm{x}}$ is the tax rate on investment, and $\tau_{\mathrm{h}}$ is the marginal labor tax rate; $r_{t}$ stands for the rental price of capital and $\tau_{\mathrm{k}}$ is the capital income tax rate. $T_{t}$ represents government transfers at time $t$ that are financed by taxes. $w_{t}$ is the price of labor, therefore $\left(w_{t} h_{t}\right)$ represents labor income. 
The standard first-order conditions indicate that the marginal rate of substitution between leisure and consumption is equal to the ratio of their prices, and that labor is paid its marginal product. The first-order conditions imply

$$
h_{t}=(1-\theta) /\left\{1-\theta+\frac{c_{t}}{y_{t}} \frac{\gamma}{(1-\tau)}\right\}
$$

where $\tau=\left(\tau_{\mathrm{h}}+\tau_{\mathrm{c}}\right) /\left(1+\tau_{\mathrm{c}}\right)$, which is the effective marginal tax rate on labor income. It represents the combined labor and consumption taxes exerted on labor income, holding investment constant. Equation (3) depicts the supply of hours worked. Because the effective marginal tax rate on labor income, $\tau$, is embedded in one of the first-order conditions, it is also in equation (3): an increase in the tax rate $\tau$ reduces labor supply $h_{t}$.

Much attention has been devoted to the investigation of the impact of taxes on hours worked at a cross-section of countries, or by using the variation in the tax rates of countries over a period of time. On the other hand, the impact of marginal utility of leisure on hours worked (which is depicted by $\gamma$ in Equation 3), has not been investigated, despite the fact that it has been postulated to be a potentially important factor to explain cross-country differences in labor supply. An increase in $\gamma$ has a negative impact on hours worked. As we describe in the next section, we develop measures of $\gamma$ to represent the value of leisure that can vary between countries.

Equation (3) provides a framework in which labor supply depends on taxes and tastes for leisure. We will not estimate the specific structural parameters, based on the specific form depicted by Equation (3). Rather, as shown below, we will estimate a linear formulation of labor supply, which depends on personal attributes of individuals, country characteristics including taxes, and measures of taste for leisure. 
Although we use survey data on individuals from various years, there is no substantial variation in marginal taxes over the years in a country. Thus, our elasticity estimates can be interpreted as steady-state elasticities. As we explain in the next section, we estimate elasticities both at the extensive and intensive margins.

\section{Empirical Implementation}

Consistent with the theoretical framework described in the previous section, we estimate the following specification to investigate the impact of taxes and taste for leisure on labor supply:

$$
\mathrm{h}_{i j n t}=\beta_{0}+\beta_{1} \tau_{j}+\beta_{2} \mathrm{~L}_{\mathrm{n}}+\mathbf{X}_{\mathrm{i}} \Phi+\mathbf{C}_{j} \boldsymbol{\Omega}+\mathbf{C O}_{n} \boldsymbol{\Psi}+\delta_{\mathrm{t}}+\boldsymbol{\varepsilon}_{i j n t},
$$

where $\mathrm{h}_{i j n t}$ stands for the labor supply of person $i$ who is a second-generation immigrant, living in country $j$, surveyed at time $t$. Labor supply is measured both at the extensive and intensive margins, allowing us to estimate models for labor force participation and for hours worked, conditional on participation. The subscript $n$ represents the country-of-origin of this person's father (who migrated from country $n$ to country $j$ ). The vector $\mathbf{X}_{i}$ includes personal attributes of individual $i$ that may impact his/her labor supply decision such as age, completed years of education, marital status, whether the person perceives him/herself as an ethnic minority in that country, and the size of the city of residence. The vector $\boldsymbol{C}_{\boldsymbol{j}}$ controls for the attributes of the country of residence that may influence labor supply through their impact on aggregate labor productivity, institutional factors and so on. The vector $\boldsymbol{C}_{\boldsymbol{j}}$ includes GDP per capita, average educational attainment in the country, the extent of the individualistic culture in the country, index of ethno-linguistic fragmentation, size of the population, legal origin indicators, and number of years in which country experienced 
democracy between 1930 and 1995. CO$_{n}$ contains attributes of the country of ancestry, such as the index of ethno-linguistic fragmentation, legal origin indicators, and a measure of democracy in father's country of origin. Time fixed-effects, $\delta_{t}$, account for the year in which individuals are surveyed. Standard errors are clustered at the country of origin.

The variable $\tau$ measures the effective marginal tax rate on labor income in country $j$ where person $i$ resides and works. We follow closely the literature, and as detailed in the next section, use country-specific tax rates generated by the previous research (Prescott 2004, McDaniel 2011). Although we use surveys of individuals from different years, the two measures of taxes we employ (the effective marginal tax rate, as well as the average tax rate for a single person without a dependent) do not change appreciably within a country in the sample period. Thus, the impact of taxes on labor supply is identified from cross-country variation in tax rates.

$\mathrm{L}_{\mathrm{n}}$ stands for various measures of the culture of leisure in the country of origin, constructed by using data from the World Values Survey and the European Values Study. For example, one particular question in these surveys is: "How important is leisure in your life?" Possible answers range from 1 (not important) to 4 (very important). The average value of answers to this question was 3.5 in Sweden, 3.3 in Uruguay, 2.9 in Morocco, and 2.6 in China, suggesting that people in Sweden value leisure more strongly in comparison to those who live in Morocco or in China, for example. Other examples of indicators for culture of leisure are responses to such statements as "People who don't work turn lazy" (agreedisagree on a scale from 1 to 5) and "Work is a duty to society" (agree-disagree from 1 to 5). The details of these and other measures of culture of leisure in the country of origin are explained in the data section. 
The framework shown in Equation (4) is termed an "epidemiological" approach by Fernández $(2008,2007)$ because it aims to identify the impact of inherited, pre-existing factors on behavior, holding constant the context in which the decision takes place. Note that reverse causality from labor supply to "taste for leisure" is unlikely to be an issue here because the labor supply decision of the individual cannot have an impact on the extent of the taste for leisure in father's country of origin. Similarly, an individual's labor supply is not expected to have an immediate impact on the tax rate in her country of residence. Even if the government wanted to react to a variation in aggregate hours worked in the economy by altering the tax rates, it cannot do so quickly, because it is well known that the inside-lags are substantial in case of fiscal policy. In other words, changes in taxes necessitate negotiations both in the parliament and with different constituents including labor unions. Because of the lags in legislative implementation, it is implausible that tax rates would react contemporaneously to a change in the aggregate hours worked in the economy. Neither the tax rates nor aggregate labor supply vary significantly within a country from year to year. For example, in Germany average hours worked per working-age population were 1,065 in $2008,1,057$ in 2010 , and 1,067 in 2012. We display the aggregate hours worked and the effective marginal tax rate for France, Germany, the U.K. and Belgium from the OECD data over the period of 2000-2012 in Table 2. ${ }^{5}$ There is no systematic change in hours worked or in the tax rate in these countries over the course of these 13 years. When we calculate the year-to-year change in average hours worked and in the effective marginal tax rate over the same period for the 26 European countries used in the analysis, we find that the average

\footnotetext{
${ }^{5}$ The descriptions effective marginal tax rate of the country and its source are provided in the data section.
} 
annual growth rate is essentially zero for both hours worked and taxes (the average growth rate is -0.002 in case of annual hours and 0.0002 in case of taxes).

It could be possible, however, that both country-level taxes and individual labor supply are driven by certain socio-economic and cultural attributes of the country. For example, societies can be rated on a scale ranging from "individualistic" to "collectivist" using the index of individualism, developed by Hofstede (2001) and Hofstede (2005). ${ }^{6}$ Lower values indicate the higher extent of collectivism of the society, which stands for the extent to which individuals are integrated into groups. In collectivist societies, people from birth onwards are integrated into strong, cohesive in-groups, often extended families (with uncles, aunts and grandparents) which continue protecting them in exchange for unquestioning loyalty. Higher values of the index represent individualistic societies where the ties between individuals are loose, and where people are expected to look after themselves and their immediate family. ${ }^{7}$ There is substantial variation around the world in the extent to which countries are individualistic or collectivist. For example Australia is rated a highly individualistic country with a score of 90 (out of 100), and the most collectivist societies are Colombia with a score of 13, Indonesia with a score of 14 and Costa Rica with a score of 15. It could be the case that the extent of individualism in the country may be correlated with the peoples' desired level of government regulation and tax rates, as well as with the extent of the labor supply. We control for individualism in the country to account for such an effect.

Similarly, we control for other potential factors that may impact both taxes and labor supply. They include per capita income in the country, the size of the population, the extent

\footnotetext{
${ }^{6}$ The data are downloaded from http://www.geert-hofstede.com/hofstede dimensions.php.

${ }^{7}$ The description is obtained from (http://www.geert-hofstede.com/geert_hofstede_resources.shtml).
} 
of ethno-linguistic fragmentation in the country, as well as the extent of democracy. We also control for the legal origin of the country. These indicators account for whether the country's legal origin is British common law, French commercial code, socialist or communist law, German commercial law or Scandinavian commercial law. These variables are explained in the descriptive statistics Table 4.

First-generation immigrants are a self-selected group of people who chose to leave their country-of-origin and decided to migrate to another country. Thus, their unobserved attributes, including the propensity to work, may be different from the general population. This issue, however, is not relevant for second-generation immigrants who are born in the country of residence. Although these individuals have inherited the genetic attributes of their immigrant parents, including perhaps an attitude towards work, this is not expected to create a bias in our estimated coefficients unless one is prepared to argue that different countries of origin have identical distributions of taste for leisure but that first-generation immigrants from different countries are selected from different parts of this distribution. ${ }^{8}$ Note also that cultural assimilation of the second-generation immigrants would make it difficult to identify a statistically significant impact of culture of leisure on labor supply, even if it existed.

We also estimate alternative versions of Equation (4) as shown below.

$$
\begin{aligned}
& \mathrm{h}_{i j n t}=\alpha_{0}+\alpha_{1} \tau_{j}+\mathbf{X}_{\mathrm{i}} \Theta+\mathbf{C}_{j} \boldsymbol{\Xi}+\xi_{\mathrm{t}}+\mu_{\mathrm{n}}+\mathbf{v}_{i j n t,} \\
& \mathrm{~h}_{i j n t}=\lambda_{0}+\lambda_{1} \mathrm{~L}_{\mathrm{n}}+\mathbf{X}_{\mathrm{i}} \Lambda+\mathbf{C O}_{n} \boldsymbol{\Gamma}+\theta_{\mathrm{t}}+\omega_{\mathrm{j}}+\mathrm{u}_{i j n t},
\end{aligned}
$$

In equation (5) we replace all country-of-origin variables by country-of-origin fixedeffects $\left(\mu_{n}\right)$. This specification does not contain measures of culture of leisure, but it still includes country-of-residence attributes as well as the tax rate in the country of origin.

\footnotetext{
${ }^{8}$ See Fernández (2011) for more on this point.
} 
Analogously, in Equation (6), the country-of residence variables, including the tax rate, are replaced by country-of-residence fixed-effects $\left(\omega_{j}\right)$, whereas variables measuring country-oforigin attributes, including proxies for culture of leisure, are retained. Equation (5) allows us to investigate the sensitivity of the tax impact when we control for country-of-origin differences by a set of country-of-origin fixed effects. Equation (6) does the reverse: it allows us to analyze the sensitivity of the culture-of-leisure coefficient when we control for the attributes of the countries of residence by a set of country-of-residence fixed-effects.

\section{Data and Descriptive Statistics}

The analyses are based on a number of different data sets. Data on labor supply and personal attributes of individuals are from the European Social Survey (ESS). We use five cross-sectional rounds of the ESS, conducted biennially between years 2004 and 2013. The ESS covers 35 European countries that participated in at least one round of the survey. We include in our analysis 26 countries for which the OECD tax data are available. The core module of the ESS is administered in all rounds and contains information about respondents' socio-economic circumstances, including employment history and work-related variables. Starting with the second round, the ESS asks its respondents the countries in which their mother and father were born, in addition to asking about respondent's own country of birth. Our sample consists of second-generation immigrants. These individuals were born in their country of residence but their fathers have migrated from a different country.

\section{Outcomes and Personal Attributes}

The two outcome variables are labor force participation and hours of work for the individual. The labor force participation variable takes the value of one if the individual 
reported being engaged in any paid work in the last 7 days or has been unemployed and is actively looking for a job. The second measure of labor supply measures the intensive margin, where the outcome is hours normally worked in a week at the main job. This information is obtained from individuals who are either working at the time of the interview or have worked in the past. In the former case, hours worked pertains to hours at the current job, while in the latter case, hours worked corresponds to the hours worked at the respondents' last job. We know the year in which this last job was held and we limit our sample to those who last worked in the year 2000 or later. The reason is twofold: first, the OECD tax measure is only available after year 2000, and second, measurement error is likely to increase as people have to recall their weekly work hours from further back in the past.

Table 4 presents the descriptive statistics of the sample used in the hours worked equation. The descriptive statistics of the sample used in participation regressions are provided in the Appendix Table 2. Although the samples in the labor force participation and the hours regressions are different by design, their descriptive statistics are similar. The first panel of Table 4 presents the summary statistics by dividing the sample by gender of the worker, as well as by the availability of the tax measure. Average weekly hours worked is about 36 for females and 43 for males. Average age is about 40 for both sexes and average years of schooling is around 13.5.

\section{Tax Measures}

We employ two different tax measures. Our first tax measure comes from the OECD Tax Database. It is the average personal income tax and the social security contribution rate on gross labor income for a single person without a dependent. This tax measure is available 
for 26 countries in the ESS for all years from 2000 to 2013. Our second tax measure is the effective marginal tax rate on labor income $(\tau)$ as used by others (e.g. Prescott 2004, McDaniel 2011). We use the average tax series updated by McDaniel (2014) to construct $\tau .{ }^{9}$ This tax measure is not available for all 26 countries and for all years for which the OECD average tax rate is available. In particular, Estonia, Iceland, Israel, Luxembourg, and Turkey have missing data for all years. Thus, the regressions that use $\tau$ are based on smaller samples. Table 3 displays the tax rates for countries in which the individuals in our sample reside. The two measures are highly correlated with a correlation coefficient of 0.75 . The tax variables are merged with the individual-level data based on the year of work when the outcome is the weekly hours normally worked, and based on the year of interview when the outcome is labor force participation.

\section{Measures of Culture of Leisure in the Country of Origin}

To construct culture of leisure measures, we use data from the World Values Survey (WVS) and the European Values Study (EVS). We employ the five cross-sectional waves of the WVS (1981-1984, 1990-1993, 1995-1997, 1999-2004, and 2005-2009). The WVS coverage starts with 22 countries in the 1981-1984 wave, and reaches 87 countries by the time of the 2005-2009 wave. The WVS asks its respondents about their attitudes regarding a variety of topics, including religion, political preferences, family values and work ethics.

The European Values Study (EVS) consists of four waves of cross-sectional surveys conducted in 49 predominantly European countries (1981-1984, 1990-1993, 1999-2001, and 2008-2010). The formulation of EVS questions about attitudes to work and leisure is

\footnotetext{
${ }^{9}$ Our calculation of $\tau$ follows the formulation of Prescott (2004) and McDaniel (2011):

$\tau=\frac{\tau_{s S}+1.6 * \tau_{i n c}+\tau_{c}}{1+\tau_{c}}$, where $\tau_{s s}, \tau_{i n c}$, and $\tau_{c}$ are taken from McDaniel (2014) data.
} 
identical to the WVS formulation. By pooling the WVS and the EVS, we are able cover a large number of countries around the world to gauge the beliefs about the importance of work and leisure in people's lives in these countries. When using WVS/EVS to measure preferences towards leisure, we have excluded immigrants whenever information on immigration status was available.

The descriptions of the variables and their sample means and standard deviations are provided in Panel B of Table 4. We created five variables to measure the extent of culture of leisure. Higher values of each variable represent a higher appreciation of leisure in that country. The first variable "Leisure Important" is the average response in the country to the question "Indicate how important leisure time is in your life." Potential answers range from 1: Not at all important to 4: Very important. Table 4 shows that for individuals who enter the hours of work regressions the average value of this variable is 3.1. Appendix Table 1 displays the average response to Leisure Important variable in each of the 81 countries that represented the country-of-origin of the immigrant father. For example, the value of Leisure Important is 2.60 in Albania. ${ }^{10}$ In comparison, the average value of Canada is 3.28, indicating that Canadians attach a higher value to leisure than Albanians do. ${ }^{11}$

The second variable that gauges culture of leisure in a country is based on the question of "Do you agree or disagree with the statement: People who don't work turn lazy." Possible answers range from 1: Strongly agree to 5: Strongly disagree. A higher value indicates a more tolerant attitude towards not working. The third and fourth variables in this group are measured similarly, and they are based on answers to the following questions: " $D o$

\footnotetext{
${ }^{10}$ This number is the average response of 3,466 Albanians surveyed in various waves of the WVS and the EVS between 1994 and 2008.

${ }^{11}$ The average Canadian response is based on 5,442 Canadians who were surveyed in various waves between 1990 and 2007.
} 
you agree or disagree with the statement: Work is a duty toward society," and "Do you agree or disagree with the statement: Work should always come first, even if it means less spare time." A fifth variable is created to measure the extent of appreciation of leisure in a country by calculating the proportion of people in the country who believe that provision of generous holidays is an important aspect of a job.

Finally, we created two other measures that capture the extent of labor market attachment in the country-of-origin. They are the labor force participation rates and average weekly hours worked in father's country-of-origin. Labor force participation in the country of ancestry has been used before as a cultural proxy for work (Fernádez and Fogli 2009, Fernández and Fogli 2006). We calculate these variables by gender. This allows us to conduct more nuanced analyses. For example, we can investigate how the labor supply decision of a female second-generation immigrant in Europe is impacted by the intensity of labor market activity of women in the country from which this person's father migrated. Furthermore, we fine-tuned this measure to connect it to the relevant age groups using the age bands of $15-24,25-54$ and $55-64 .{ }^{12}$

Similarly, we obtained weekly hours actually worked per employed person in the country of origin. The data come from the International Labor Organization ILOSTAT Database. Because the annual data are not available for every year and country, we use averaged available values over the time period 2000 to 2013. The ILOSTAT indicator covers both employees and self-employed and it counts hours people have worked either on all jobs,

\footnotetext{
${ }^{12}$ For example, we connected the propensity to participate in the labor market of a female $2^{\text {nd }}$ generation immigrant in Europe who is 20 years old to the labor force participation rate of women ages 15-24 in her father's country of origin. Country-age-and gender specific labor force participation rates were obtained from the International Labor Organization ILOSTAT database. Because the annual data are not available for every year, country, and age band, we use averaged available values over the time period 2002 to 2013.
} 
or, in some country-years, at the main and second job only. Both part-time and full-time employment hours are accounted for. ${ }^{13}$ Our measure of weekly hours in the country of origin is gender-specific, but not age-group specific, as the ILOSTAT does not provide age groupspecific indicator.

\section{Country Attributes}

In each specification, we also control for country characteristics both in the country of respondent's residence and in his/her father's country of origin. These variables include ethno-linguistic fragmentation, the legal origin of the country, and the number of years in which the country was democratic from 1930 to 1995 . Additionally, the models include per capita income, average country education, population size, and individualism index in the country of residence.

\section{$\underline{\text { V. Results }}$}

Table 5 displays the summary results for females. Panel A presents the coefficients of tax and culture variables in the labor force participation equation, and Panel B presents the estimated tax and culture coefficients from the hours equation for those who reported positive work hours. All models include control variables pertaining to the individual, country of ancestry and country of residence. These variables are listed in panels A, C, and D of Table 4. The coefficients of these variables are not reported in the interest of space,

\footnotetext{
${ }^{13}$ In addition, the ILOSTAT provides a number of flags indicating data inconsistencies that can complicate analysis across time and countries. For example, in China, Costa Rica, Guatemala, Egypt, Pakistan, Panama, Viet Nam, and Zimbabwe only full-time employment hours are counted, and we exclude these countries from our sample.
} 
although in Appendix Table 3 we display the full set of coefficients of the model in column (1) of Panel A in Table 5.

Table 5 presents six specifications in six columns. Each specification includes a different culture of leisure construct, which is displayed at the column header. For example, in model of column (1) culture of leisure is measured by the mean value of the question that gauges the importance of leisure in people's lives (Leisure Important). Similarly, in column (2) culture of leisure is measured by responses to the statement of "People who don't work turn lazy" in the country of origin. Higher values of culture variables in columns (1) to (5) indicate stronger preference for leisure. Thus, the estimated coefficient of culture of leisure in these columns is expected to be negative. In column (6), culture is measured by the labor force participation rate in the country of origin when we estimate models on the extensive margin (Panel A), or as the average hours worked in the country of origin when we estimate models on the intensive margin (Panel B). The coefficients of these variables are expected to be positive to the extent that work effort in the country of ancestry is a cultural attribute transmitted to the offspring.

Both Panels A and B of Table 5 have two sections. The models in the top section of each panel use the first tax measure (average tax), while the models in the bottom section employ $\tau$ (effective marginal tax) as the measure of the tax rate in the country. Panel A of Table 5 shows that taxes have a negative impact on female labor force participation in all models when taxes are measured by the average tax. The same is true also in models where taxes are measured by the effective marginal tax rate $\tau$, although the point estimates are significant only at the $12-15$ percent level in models of columns (1) to (4). 
Culture of leisure in the country of origin has a negative and statistically significant impact on female labor force participation in models displayed in columns (1) and (5) where culture is measured by people's valuation of leisure (leisure is important) and by valuation of the generous holidays attached to a job; In the regression reported in column (6), culture of leisure is measured by female labor force participation in the country-of-ancestry; and its coefficient is positive as expected.

Panel B presents the results where the dependent variable is hours worked for females, conditional on working. Both higher taxes in the country of residence and higher culture of leisure in the country of origin reduce female hours. Culture coefficients are statistically different from zero in models 2,3 , and 4 when taxes are measured by average personal income tax rate for a single person without a dependent, and in models 2, 4 and 5 with effective marginal tax rate on labor income. The picture that emerges in Table 5 is that for females, taxes have a negative impact on labor supply both at the extensive and intensive margins, and culture of leisure also negatively impacts labor supply, although the precision of the estimated coefficients varies between specifications.

Table 6 reports the results of the same models for males. In Panel A we observe that taxes have a negative impact on labor force participation, regardless of the measure of culture and regardless of the measure of taxes. On the other hand, the coefficients of culture variables are never statistically different from zero. Panel B summarizes the models that investigate hours worked for males, conditional on working. While there is evidence on the impact of taxes on labor male labor supply, culture of leisure has no impact on hours worked for males. 
In Table 7 we summarize these results by reporting them in elasticity form. The elasticities with respect to taxes are based on median estimate of the effective marginal tax rate coefficients, and the elasticity with respect to culture is the median estimate within the relevant panels of Tables 5 and 6 . The implied aggregate hours elasticity for taxes is -0.42 for females and -0.27 for males. ${ }^{14}$ The impact of culture of leisure, expressed in elasticity terms, is smaller than the impact of taxes, but still sizable for female labor supply, while culture of leisure has no impact on men's labor market activity.

To put these elasticities in perspective, note for example, that in Belgium average hours per working age population was 989 in 2012, and the effective marginal tax rate is 57\%. In Portugal, average hours worked in 2012 was 1,237 and the effective marginal tax rate is $41 \%$. If the tax rate in Belgium goes down 16 percentage points to bring it down to the level prevailing in Portugal, this would be a 28 percent reduction and using the elasticity estimates for men and women in Table 7, and using the weights of men and women in employment, we find that aggregate hours would go up by $9 \%$ or by 93 hours per workingage person. This would help close the gap in hours of work between Belgium and Portugal (see Table 1) by about $45 \%$. This is possibly an under-estimate because the elasticity we use is uncompensated, and it does not take into account the income effect.

The mean value of the response to the question of "Work is Duty towards Society" (1: Strongly Agree, 5: Strongly disagree) is 2.3 in Belgium. If the tastes for leisure were weaker so that the mean response to this question was 1.91 (the level in Portugal), this would constitute a $17 \%$ decline in the intensity of tastes for leisure. This change in preferences would impact hours worked only through its effect on females, because in case of males

\footnotetext{
${ }^{14}$ These estimates are smaller than those summarized by Chetty et al. (2011) but the numbers reported in Table 7 are uncompensated elasticities, while the ones reported by Chetty et al. (2011) are compensated elasticities.
} 
neither participation nor hours respond to changes in culture of leisure. The impact on aggregate hours worked per working age population would be an increase by 39 hours (about 4\%). This would close the gap in hours worked between Belgium and Portugal by $20 \%$.

Table 8 reports the same models reported earlier, but these models include countryof-origin fixed-effects. As a result, we cannot identify the impact of leisure variables, but we can investigate whether the impact of taxes is altered by this specification. Table 8 displays the coefficients of the average and marginal taxes in both the participation and hours equations. They are very similar to those reported in Tables 5 and 6 .

Tables 9 and 10 display the results of the analogous exercise, but in this case, we replace the country-of-residence variables, including the tax rates, with country of residence dummies. Country-of-origin variables, including leisure measures, are retained. Table 9 presents the results for females. The estimated coefficients of various measures of leisure are consistent with the ones reported earlier in both participation and hours decisions, but the statistical significant is spotty. The results for males, shown in Table 10, are also consistent with those reported earlier: taste for leisure is not a statistically significant determinant of men's labor market activity.

\section{$\underline{\text { VI. Summary and Conclusion }}$}

There are substantial differences in aggregate hours worked between countries. In an influential paper, using a growth model Prescott (2004) argued that virtually all of the difference in hours worked between the U.S. and Europe can be explained by the differences in tax rates. A large literature that followed Prescott (2004) provided various extensions 
ranging from consideration of households' self-insurance through asset accumulation (Ljungqvist and Sargent 2006) to incorporation of household production (McDaniel 2011).

Taxes distort the margin at which the market labor supply decision is made and higher taxes on labor income motivate people to shift away from market work to leisure. The large magnitude of the labor supply response in the Prescott framework, however, prompted the skeptics to suggest alternative or complementary mechanisms to explain the labor supply differences between countries, including the importance of regulations and labor unions (Alesina, Glaeser and Sacerdote 2005). One important point in this framework is the assumption of homogeneous preferences between countries. While it has been explicitly acknowledged that preferences for leisure may not be identical between countries (Blanchard 2006), no research has addressed the question of whether or not the "taste for leisure" has a role in labor supply differences.

In this paper we use micro data from European Social Survey that include information on labor force participation and hours worked of second-generation immigrants who reside in 26 European countries. These individuals are born in Europe, and they have been exposed to institutional, legal and labor market structures of their countries, including the tax rates. Fathers of these individuals are first-generation immigrants and our data allow us to identify 81 different countries they migrated from. We follow the recent literature on the impact of culture on economic behavior (Alesina et al. 2015, Alesina and Giuliano 2010, Fernández 2011) and use immigrant father's country of birth to determine the ancestral roots, and assume that culture of leisure in father's country of origin is transmitted from the immigrant father to the offspring. 
Using the World Values Survey and the European Values Study, we construct measures of "taste for leisure" in the country of origin of each immigrant father. These measures include average responses in a country to such questions as "How Important is leisure time in your life?" "Do you agree or disagree with the statement: People who don't work turn lazy." "Do you agree or disagree with the statement: Work is a duty to society." "Do you agree or disagree with the statement: Work should always come first even if it means less spare time." The details of these and other variables that aim to gauge the extent of culture of leisure in the country of origin are provided in the paper.

We employ two different tax measures. The first one is the average personal income tax and the social security contribution rate on gross labor income for a single person without a dependent. The second one is the effective marginal tax rate on labor income. We control for individual characteristics such age, education, marital status, size of the city and ethnic minority status. We also control for a set of attributes of the country of residence and country of origin, ranging from per capita income to legal origin of the country. Thus, we are able to identify the impact of taxes on labor supply (both at the extensive and intensive margin), holding constant observable attributes of individuals, various attributes of the country in which they live, and attributes of their father's country of origin, including the taste for leisure in that country of origin. Similarly, we can identify the impact of culture of leisure on labor supply, holding constant personal characteristics, and country attributes, including taxes.

The results show that for women, both taxes and culture of leisure impact participation and hours worked. For men, taxes influence labor supply both at the intensive and the extensive margin, but culture of leisure has no impact. We find uncompensated aggregate 
labor supply elasticity of -0.42 for women and -0.27 for men. The elasticity for "taste for leisure" is -0.24 for women and zero for men. These results suggest that while labor income tax is a significant determinant of aggregate hours worked, culture of leisure in the country is important as well.

Although we do not address the question of "what determines the difference in culture of leisure between countries?" we should emphasize that recent research has shown that cultural attributes are malleable, and they react to external factors. For example, Fernández (2013) shows that social attitudes towards women's work endogenously change over time. Alesina and Fuchs-Schündeln (2007) find that individual preferences are shaped by the political regime in which they lives. Giuliano and Spilimbergo (2014) report that individuals' political preferences and their support for government redistribution policies are impacted by whether or not they grew up during recessionary periods. Cannonier and Mocan (2012) find that women in Sierra Leone, whose years of schooling is increased by an education reform, are more likely to disapprove certain cultural norms and behaviors. Tastes for leisure, too, are likely to evolve over time as a cultural attribute. A simple example is the one given by Alesina, Glaeser and Sacerdote (2006) who suggest that an initial decline in market work might increase individuals' utility from leisure and this process can be amplified by a social multiplier (Glaeser, Sacerdote and Scheinkman 2003) if there exist complementarities in leisure. But, regardless of whether culture of leisure evolves gradually or slowly over time, our results indicate that people would work less in a country if the taste for leisure is stronger in that country. 


\section{Table 1}

Hours Worked Per Capita (ages 15-64) in Selected OECD Countries in 2012. Hours Worked per Working Age Person (Indexed to $\mathrm{UK}=100$ )

\begin{tabular}{lc}
\hline United Kingdom & 100 \\
France & 81 \\
Austria & 103 \\
Germany & 90 \\
Italy & 95 \\
Turkey & 74 \\
Belgium & 84 \\
Denmark & 93 \\
Sweden & 104 \\
Netherlands & 95 \\
Spain & 84 \\
Greece & 97 \\
Portugal & 104 \\
\hline
\end{tabular}

Source: OECD Labor Database and OECD Productivity Database. 
Table 2

Average Hours Worked and the Effective Marginal Tax Rate in Selected European Countries 2000-2012.

\begin{tabular}{|c|c|c|c|c|c|c|c|c|}
\hline & \multicolumn{2}{|c|}{ France } & \multicolumn{2}{c|}{ Germany } & \multicolumn{2}{c|}{ United Kingdom } & \multicolumn{2}{c|}{ Belgium } \\
\hline & $\begin{array}{c}\text { Hours } \\
\text { worked per } \\
\text { working } \\
\text { Yge } \\
\text { Year }\end{array}$ & $\begin{array}{c}\text { Effective } \\
\text { marginal } \\
\text { tax rate }\end{array}$ & $\begin{array}{c}\text { Hours } \\
\text { worked per } \\
\text { working } \\
\text { age } \\
\text { population }\end{array}$ & $\begin{array}{c}\text { Hours } \\
\text { Effective } \\
\text { marginal } \\
\text { tax rate }\end{array}$ & $\begin{array}{c}\text { Hours } \\
\text { worked per } \\
\text { working } \\
\text { age } \\
\text { worked } \\
\text { per }\end{array}$ & $\begin{array}{c}\text { Effective } \\
\text { marginal } \\
\text { tax rate }\end{array}$ & $\begin{array}{c}\text { Effective } \\
\text { working } \\
\text { age } \\
\text { population }\end{array}$ & $\begin{array}{c}\text { marginal } \\
\text { tax rate }\end{array}$ \\
\hline 2000 & 995 & 55.5 & 1,045 & 52.7 & 1,217 & 44.1 & 976 & 58.0 \\
2001 & 997 & 54.8 & 1,037 & 52.4 & 1,218 & 44.1 & 982 & 57.8 \\
2002 & 969 & 54.3 & 1,026 & 52.3 & 1,209 & 43.2 & 972 & 58.6 \\
2003 & 960 & 54.6 & 1,014 & 52.6 & 1,203 & 42.8 & 965 & 58.0 \\
2004 & 972 & 54.7 & 1,021 & 51.5 & 1,191 & 43.3 & 966 & 58.2 \\
2005 & 968 & 55.2 & 1,007 & 51.4 & 1,204 & 43.6 & 970 & 57.6 \\
2006 & 956 & 55.2 & 1,029 & 51.7 & 1,200 & 43.6 & 977 & 56.6 \\
2007 & 974 & 54.7 & 1,053 & 52.2 & 1,199 & 43.9 & 986 & 56.3 \\
2008 & 979 & 54.7 & 1,065 & 52.6 & 1,190 & 43.8 & 991 & 56.4 \\
2009 & 953 & 54.8 & 1,038 & 52.6 & 1,156 & 42.9 & 971 & 56.2 \\
2010 & 954 & 54.4 & 1,057 & 51.3 & 1,154 & 43.2 & 973 & 56.5 \\
2011 & 962 & 55.6 & 1,071 & 51.4 & 1,157 & 43.9 & 988 & 56.9 \\
2012 & 960 & 56.9 & 1,067 & 52.1 & 1,182 & 43.3 & 989 & 57.7 \\
\hline
\end{tabular}

Source: Hours worked per working age population are constructed using data from the OECD Labor Database and the OECD Productivity Database. $\tau$ is the effective marginal tax rate on labor income (Prescott 2004). Our calculation of $\tau$ follows the formulation of Prescott (2004) and McDaniel (2011): $\tau=\frac{\tau_{s S}+1.6 * \tau_{i n c}+\tau_{c}}{1+\tau_{c}}$, where $\tau_{s S}, \tau_{i n c}$, and $\tau_{c}$ are taken from McDaniel (2014) data. 
Table 3

Taxes in Countries of Residence.

\begin{tabular}{lcc}
\hline \multicolumn{1}{c}{ Country } & $\boldsymbol{\tau}$ & Average Personal IncomeTax \\
\hline Austria & 56.497 & 32.763 \\
Belgium & 57.293 & 42.427 \\
Czech Republic & 45.076 & 22.970 \\
Denmark & 62.847 & 40.851 \\
Estonia & & 20.193 \\
Finland & 55.740 & 30.787 \\
France & 55.252 & 28.284 \\
Germany & 52.082 & 41.531 \\
Greece & 42.194 & 24.171 \\
Hungary & 52.668 & 35.554 \\
Iceland & & 27.340 \\
Ireland & 41.181 & 16.697 \\
Israel & & 20.925 \\
Italy & 53.681 & 29.366 \\
Luxembourg & & 25.883 \\
Netherlands & 48.625 & 31.951 \\
Norway & 50.617 & 29.771 \\
Poland & 41.895 & 26.559 \\
Portugal & 40.641 & 22.666 \\
Slovakia & 39.054 & 21.653 \\
Slovenia & 45.979 & 34.223 \\
Spain & 42.124 & 20.740 \\
Sweden & 63.378 & 28.644 \\
Switzerland & 30.547 & 17.469 \\
Turkey & 43.532 & 29.602 \\
United Kingdom & & 25.813 \\
\hline The first tax measure $(\tau)$ is the effective marginal tax rate on labor income (Prescott 2004). \\
The second tax measure is the average personal income tax and social security contribution rate on \\
gross labor income is that for a single person without a dependent earning & $100 \%$ of average \\
earnings of industry workers in the country (Source: OECD Tax Database & Table 5). \\
The tax values are averaged for the period 2000 to 2013. & \\
\hline & & \\
& &
\end{tabular}


Table 4. Descriptive Statistics for the Sample of "Hours Worked"

\begin{tabular}{|c|c|c|c|c|c|}
\hline & & \multicolumn{2}{|c|}{ Females } & \multicolumn{2}{|c|}{ Males } \\
\hline Variable & Description (Source) & $\begin{array}{l}\text { avg_all_- } \\
\text { in } 100 \\
\text { sample }\end{array}$ & $\tau$ sample & $\begin{array}{l}\text { avg_all__ } \\
\text { in } 100 \\
\text { sample }\end{array}$ & $\tau$ sample \\
\hline \multicolumn{6}{|c|}{ Panel A: Personal Characteristics } \\
\hline Normal Weekly Hours & $\begin{array}{l}\text { Hours normally worked in a week at the main job } \\
\text { as reported by the ESS respondents }\end{array}$ & $\begin{array}{c}36.344 \\
(12.254)\end{array}$ & $\begin{array}{c}35.445 \\
(12.642)\end{array}$ & $\begin{array}{c}43.249 \\
(12.171)\end{array}$ & $\begin{array}{c}42.633 \\
(11.893)\end{array}$ \\
\hline Age & Age of the respondent & $\begin{array}{c}41.550 \\
(12.744)\end{array}$ & $\begin{array}{c}40.633 \\
(12.871)\end{array}$ & $\begin{array}{c}40.470 \\
(13.499)\end{array}$ & $\begin{array}{c}40.385 \\
(13.539)\end{array}$ \\
\hline Ethnic Minority & $\begin{array}{l}==1 \text { if the respondent belongs to minority } \\
\text { ethnic group in country }\end{array}$ & $\begin{array}{c}0.134 \\
(0.341)\end{array}$ & $\begin{array}{c}0.106 \\
(0.308)\end{array}$ & $\begin{array}{c}0.152 \\
(0.359)\end{array}$ & $\begin{array}{c}0.129 \\
(0.336)\end{array}$ \\
\hline Years of Schooling & $\begin{array}{l}\text { Number of years of full-time education } \\
\text { completed }\end{array}$ & $\begin{array}{l}13.630 \\
(3.501) \\
\end{array}$ & $\begin{array}{l}13.527 \\
(3.759)\end{array}$ & $\begin{array}{l}13.206 \\
(3.471)\end{array}$ & $\begin{array}{l}13.240 \\
(3.630)\end{array}$ \\
\hline Married & $==1$ if the respondent is married, 0 otherwise & $\begin{array}{c}0.557 \\
(0.497)\end{array}$ & $\begin{array}{c}0.518 \\
(0.500)\end{array}$ & $\begin{array}{c}0.540 \\
(0.499)\end{array}$ & $\begin{array}{c}0.522 \\
(0.500)\end{array}$ \\
\hline City & $==1$ if respondent lives in a big city, 0 otherwise & $\begin{array}{c}0.333 \\
(0.471)\end{array}$ & $\begin{array}{c}0.223 \\
(0.416)\end{array}$ & $\begin{array}{c}0.300 \\
(0.458)\end{array}$ & $\begin{array}{c}0.218 \\
(0.413)\end{array}$ \\
\hline \multicolumn{6}{|c|}{ Panel B: Culture of Leisure in Country of Origin } \\
\hline Leisure Important & $\begin{array}{l}\text { Average country response to the question "How } \\
\text { important is Leisure Time in your life?" } 1 \text { : 'Not } \\
\text { at all important' 2: 'Not very important' 3: } \\
\text { 'Rather important' } 4 \text { 'Very important"” (A) }\end{array}$ & $\begin{array}{l}3.071 \\
(0.196)\end{array}$ & $\begin{array}{l}3.109 \\
(0.212)\end{array}$ & $\begin{array}{l}3.079 \\
(0.191)\end{array}$ & $\begin{array}{l}3.108 \\
(0.207)\end{array}$ \\
\hline Generous Holidays & $\begin{array}{l}\text { Average country response to the question "Please } \\
\text { tell me if generous Holidays are important in a } \\
\text { job." (A): 0: Not Important, 100: Very } \\
\text { Important. }\end{array}$ & $\begin{array}{l}34.530 \\
(14.880)\end{array}$ & $\begin{array}{l}30.743 \\
(12.822)\end{array}$ & $\begin{array}{l}34.353 \\
(14.883)\end{array}$ & $\begin{array}{l}31.673 \\
(13.433)\end{array}$ \\
\hline People Turn Lazy & $\begin{array}{l}\text { Average country response to the question "Do } \\
\text { you agree or disagree with the following } \\
\text { statement: People who don't work turn lazy. } 1 \\
\text { 'Strongly agree' } 2 \text { 'Agree' } 3 \text { 'Neither agree nor } \\
\text { disagree' } 4 \text { 'Disagree' } 5 \text { 'Strongly disagree'" (A) }\end{array}$ & $\begin{array}{l}2.179 \\
(0.305)\end{array}$ & $\begin{array}{c}2.228 \\
(0.321)\end{array}$ & $\begin{array}{c}2.184 \\
(0.309)\end{array}$ & $\begin{array}{l}2.223 \\
(0.328)\end{array}$ \\
\hline $\begin{array}{l}\text { Work Is a Duty to } \\
\text { Society }\end{array}$ & $\begin{array}{l}\text { Average country response to the question "Do } \\
\text { you agree or disagree with the following } \\
\text { statement: Work is a duty towards society." } \\
\text { 1: 'Strongly agree' 2: 'Agree' 3: 'Neither agree } \\
\text { nor disagree' 4: 'Disagree' 5: 'Strongly disagree' } \\
\text { (A) }\end{array}$ & $\begin{array}{l}2.258 \\
(0.331)\end{array}$ & $\begin{array}{l}2.238 \\
(0.264)\end{array}$ & $\begin{array}{l}2.240 \\
(0.325)\end{array}$ & $\begin{array}{l}2.224 \\
(0.271)\end{array}$ \\
\hline $\begin{array}{l}\text { Work Should Come } \\
\text { First }\end{array}$ & $\begin{array}{l}\text { Average country response to the question 'Do } \\
\text { you agree or disagree with the following } \\
\text { statement: Work should always come first, even } \\
\text { if it means less spare time." } 1: \text { 'Strongly agree' } \\
\text { 2: 'Agree' 3: 'Neither agree nor disagree' 4: } \\
\text { 'Disagree' 5: 'Strongly disagree' (A) }\end{array}$ & $\begin{array}{r}2.540 \\
(0.448)\end{array}$ & 2.593 & $(0.440)$ & 2.581 \\
\hline
\end{tabular}




\begin{tabular}{|c|c|c|c|c|c|}
\hline Average Weekly Hours & $\begin{array}{l}\text { Weekly hours actually worked per employed } \\
\text { person in the country of origin (I) }\end{array}$ & $\begin{array}{l}35.646 \\
(3.635)\end{array}$ & $\begin{array}{l}35.225 \\
(3.641)\end{array}$ & $\begin{array}{l}41.978 \\
(3.165)\end{array}$ & $\begin{array}{l}41.980 \\
(3.153)\end{array}$ \\
\hline \multicolumn{6}{|c|}{ Panel C: Other Country of Origin Characteristics } \\
\hline $\begin{array}{l}\text { Ethnolinguistic } \\
\text { Fragmentation }\end{array}$ & $\begin{array}{l}\text { Roeder's } 1985 \text { Index of the extent of } \\
\text { ethnolinguistic fragmentation in the country (B) }\end{array}$ & $\begin{array}{c}0.283 \\
(0.202)\end{array}$ & $\begin{array}{l}0.256 \\
(0.213)\end{array}$ & $\begin{array}{c}0.276 \\
(0.200)\end{array}$ & $\begin{array}{c}0.260 \\
(0.214)\end{array}$ \\
\hline Democratic & $\begin{array}{l}\text { Number of years in which the country } \\
\text { experienced democracy between } 1930 \text { and } 1995 \\
\text { (C) }\end{array}$ & $\begin{array}{c}22.095 \\
(24.859)\end{array}$ & $\begin{array}{c}29.291 \\
(25.733)\end{array}$ & $\begin{array}{c}23.900 \\
(24.891)\end{array}$ & $\begin{array}{c}29.791 \\
(25.401)\end{array}$ \\
\hline British Legal Origin & $\begin{array}{l}==1 \text { if the legal origin of home country is English } \\
\text { Common Law, } 0 \text { otherwise }(\mathrm{C})\end{array}$ & $\begin{array}{c}0.109 \\
(0.312)\end{array}$ & $\begin{array}{c}0.143 \\
(0.350)\end{array}$ & $\begin{array}{c}0.108 \\
(0.310)\end{array}$ & $\begin{array}{c}0.146 \\
(0.354)\end{array}$ \\
\hline French Legal Origin & $\begin{array}{l}==1 \text { if the legal origin of home country is French } \\
\text { Commercial Code, } 0 \text { otherwise (C) }\end{array}$ & $\begin{array}{c}0.379 \\
(0.485)\end{array}$ & $\begin{array}{c}0.419 \\
(0.494)\end{array}$ & $\begin{array}{c}0.419 \\
(0.494)\end{array}$ & $\begin{array}{c}0.444 \\
(0.497)\end{array}$ \\
\hline $\begin{array}{l}\text { Socialist/Communist } \\
\text { Legal Origin }\end{array}$ & $\begin{array}{l}==1 \text { if the legal origin of home country is } \\
\text { Socialist/Communist Laws, } 0 \text { otherwise (C) }\end{array}$ & $\begin{array}{c}0.389 \\
(0.488)\end{array}$ & $\begin{array}{c}0.271 \\
(0.445)\end{array}$ & $\begin{array}{c}0.342 \\
(0.474)\end{array}$ & $\begin{array}{c}0.244 \\
(0.430)\end{array}$ \\
\hline German Legal Origin & $\begin{array}{l}==1 \text { if the legal origin of home country is } \\
\text { German Commercial Code, } 0 \text { otherwise (C) }\end{array}$ & $\begin{array}{c}0.076 \\
(0.265)\end{array}$ & $\begin{array}{c}0.106 \\
(0.308)\end{array}$ & $\begin{array}{c}0.093 \\
(0.291)\end{array}$ & $\begin{array}{c}0.119 \\
(0.324)\end{array}$ \\
\hline $\begin{array}{l}\text { Scandinavian Legal } \\
\text { Origin }\end{array}$ & $\begin{array}{l}==1 \text { if the legal origin of home country is } \\
\text { Scandinavian Commercial Code, } 0 \text { otherwise (C) }\end{array}$ & $\begin{array}{c}0.046 \\
(0.210)\end{array}$ & $\begin{array}{c}0.062 \\
(0.242) \\
\end{array}$ & $\begin{array}{c}0.039 \\
(0.193)\end{array}$ & $\begin{array}{c}0.047 \\
(0.212)\end{array}$ \\
\hline \multicolumn{6}{|c|}{ Panel D: Country of Residence Characteristics } \\
\hline avg_all_in 100 & $\begin{array}{l}\text { Average personal income tax and social security } \\
\text { contribution rate on gross labor income for a } \\
\text { single person without a dependent }(\mathrm{G})\end{array}$ & $\begin{array}{l}25.469 \\
(8.233)\end{array}$ & & $\begin{array}{l}26.389 \\
(8.589)\end{array}$ & \\
\hline$\tau$ & $\begin{array}{l}\text { The effective marginal tax rate calculated using } \\
\text { McDaniel data }(\mathrm{H})\end{array}$ & & $\begin{array}{l}49.080 \\
(9.243) \\
\end{array}$ & & $\begin{array}{l}48.844 \\
(9.305)\end{array}$ \\
\hline Per capita Income & $\begin{array}{l}\text { PPP adjusted GDP per capita in constant } 2011 \\
\text { US\$ (D) }\end{array}$ & $\begin{array}{c}35,340 \\
(11,116) \\
\end{array}$ & $\begin{array}{l}39,604 \\
(8,893) \\
\end{array}$ & $\begin{array}{c}37,505 \\
(13,343) \\
\end{array}$ & $\begin{array}{l}40,156 \\
(9,047) \\
\end{array}$ \\
\hline $\begin{array}{l}\text { Average Country } \\
\text { Education }\end{array}$ & $\begin{array}{l}\text { Average education of individuals aged } 15 \text { and } \\
\text { over in the country (E) }\end{array}$ & $\begin{array}{l}11.545 \\
(0.884)\end{array}$ & $\begin{array}{l}11.278 \\
(0.957)\end{array}$ & $\begin{array}{l}11.479 \\
(0.925)\end{array}$ & $\begin{array}{l}11.319 \\
(0.938)\end{array}$ \\
\hline Population & Country population in millions (D) & $\begin{array}{c}20.754 \\
(26.249)\end{array}$ & $\begin{array}{c}31.678 \\
(29.608)\end{array}$ & $\begin{array}{c}22.897 \\
(27.773)\end{array}$ & $\begin{array}{c}33.016 \\
(30.230)\end{array}$ \\
\hline Individualism & $\begin{array}{l}\text { Hofstede Index of the degree to which } \\
\text { individuals are integrated into groups (F) }\end{array}$ & $\begin{array}{c}63.951 \\
(11.720) \\
\end{array}$ & $\begin{array}{c}68.718 \\
(12.621)\end{array}$ & $\begin{array}{c}64.694 \\
(11.588)\end{array}$ & $\begin{array}{c}68.987 \\
(11.786)\end{array}$ \\
\hline $\begin{array}{l}\text { Ethnolinguistic } \\
\text { Fragmentation }\end{array}$ & $\begin{array}{l}\text { Roeder's } 1985 \text { Index of the extent of } \\
\text { ethnolinguistic fragmentation in the country (B) }\end{array}$ & $\begin{array}{c}0.312 \\
(0.176)\end{array}$ & $\begin{array}{c}0.279 \\
(0.188)\end{array}$ & $\begin{array}{c}0.315 \\
(0.184)\end{array}$ & $\begin{array}{c}0.288 \\
(0.198)\end{array}$ \\
\hline Democratic & $\begin{array}{l}\text { Number of years in which the country } \\
\text { experienced democracy between } 1930 \text { and } 1995 \\
\text { (C) }\end{array}$ & $\begin{array}{c}43.333 \\
(24.370)\end{array}$ & $\begin{array}{c}51.408 \\
(21.913)\end{array}$ & $\begin{array}{c}45.281 \\
(24.051)\end{array}$ & $\begin{array}{c}52.389 \\
(21.004)\end{array}$ \\
\hline British Legal Origin & $\begin{array}{l}==1 \text { if the legal origin of home country is English } \\
\text { Common Law, } 0 \text { otherwise }(\mathrm{C})\end{array}$ & $\begin{array}{c}0.300 \\
(0.458)\end{array}$ & $\begin{array}{c}0.128 \\
(0.334)\end{array}$ & $\begin{array}{c}0.247 \\
(0.431)\end{array}$ & $\begin{array}{c}0.122 \\
(0.327)\end{array}$ \\
\hline French Legal Origin & $\begin{array}{l}==1 \text { if the legal origin of home country is French } \\
\text { Commercial Code, } 0 \text { otherwise }(\mathrm{C})\end{array}$ & $\begin{array}{c}0.197 \\
(0.398)\end{array}$ & $\begin{array}{l}0.305 \\
(0.460)\end{array}$ & $\begin{array}{c}0.246 \\
(0.431)\end{array}$ & $\begin{array}{c}0.316 \\
(0.465)\end{array}$ \\
\hline
\end{tabular}




\begin{tabular}{|c|c|c|c|c|c|}
\hline $\begin{array}{l}\text { Socialist/Communist } \\
\text { Legal Origin }\end{array}$ & $\begin{array}{l}==1 \text { if the legal origin of home country is } \\
\text { Socialist/Communist Laws, } 0 \text { otherwise (C) }\end{array}$ & $\begin{array}{c}0.239 \\
(0.427)\end{array}$ & $\begin{array}{c}0.145 \\
(0.353)\end{array}$ & $\begin{array}{c}0.214 \\
(0.410)\end{array}$ & $\begin{array}{r}0.129 \\
(0.335)\end{array}$ \\
\hline German Legal Origin & $\begin{array}{l}==1 \text { if the legal origin of home country is } \\
\text { German Commercial Code, } 0 \text { otherwise }(\mathrm{C})\end{array}$ & $\begin{array}{c}0.167 \\
(0.373)\end{array}$ & $\begin{array}{c}0.284 \\
(0.451)\end{array}$ & $\begin{array}{c}0.194 \\
(0.396)\end{array}$ & $\begin{array}{c}0.304 \\
(0.460) \\
\end{array}$ \\
\hline $\begin{array}{l}\text { Scandinavian Legal } \\
\text { Origin }\end{array}$ & $\begin{array}{l}==1 \text { if the legal origin of home country is } \\
\text { Scandinavian Commercial Code, } 0 \text { otherwise (C) }\end{array}$ & $\begin{array}{c}0.097 \\
(0.297)\end{array}$ & $\begin{array}{c}0.138 \\
(0.345)\end{array}$ & $\begin{array}{c}0.099 \\
(0.299)\end{array}$ & $\begin{array}{r}0.130 \\
(0.336)\end{array}$ \\
\hline $\mathrm{N}$ & & 3,043 & 1,785 & 2,887 & 1,834 \\
\hline
\end{tabular}

Notes: Personal characteristics variables data come from the ESS survey. The question about hours normally worked in a week refers to the respondent's current job if he or she is currently employed and to the most recent job if he or she is unemployed at the time of the interview. We restrict our sample to second-generation immigrants who are either working at the time of the interview or have held their last job in year 2000 or later and are/were between 16 and 64 years of age at the time of working. We also exclude individuals who reported either zero hours normally worked or more than 100 hours. Survey weights are used.

avg_all_in100 sample includes the following countries of destination: Austria, Belgium, Czech Republic, Denmark, Estonia, Finland, France, Germany, Greece, Hungary, Iceland, Ireland, Israel, Italy, Luxembourg, Netherlands, Norway, Poland, Portugal, Slovak Republic, Slovenia, Spain, Sweden, Switzerland, Turkey, and the United Kingdom.

$\tau$ sample includes the following countries of destination: Austria, Belgium, Czech Republic, Denmark, Finland, France, Germany, Greece, Hungary, Ireland, Italy, Netherlands, Norway, Poland, Portugal, Slovak Republic, Slovenia, Spain, Sweden, Switzerland, and the United Kingdom.

Depending on specification, measures of culture of leisure are available for the following number of observations: Leisure Important - from to 1,785 to 3,043; Generous Holidays - from 1,742 to 2,916; People Turn Lazy, Work Is a Duty to Society, and Work Should Come First - from 1,675 to 2,801; Country of Origin Average Hours - from 1,467 to 2,004. A: World Values Survey and European Values Study data. The original variable Leisure Important had reverse scale; it was recoded so that higher values correspond to "lazier" culture.

B: Philip G. Roeder, 2001. "Ethnolinguistic Fractionalization (ELF) Indices, 1961 and 1985"

<http://pages.ucsd.edu/ proeder/elf.htm>; C: Teorell, Jan, Nicholas Charron, Stefan Dahlberg, Sören Holmberg, Bo Rothstein, Petrus Sundin \& Richard Svensson, 2013. “The Quality of Government Dataset” version qog_std_cs_20dec13 <http://www.qog.pol.gu.se>; D: World Bank's World Development Indicators Database $<$ http://databank.worldbank.org /data/databases.aspx>; E: Barro and Lee data set version BL2013_MF1599_v2.0

<http://www.barrolee.com/data/full1.htm>. The variable is available for the years 2000, 2005, and 2010; the values in between are interpolated; years 2010, 2011, 2012, and 2013 are assigned the 2010 value; F: Hofstede, G. "Cultural Dimensions" <http://geert-hofstede.com/countries.html>. G: OECD Tax Database Table 5

<http://stats.oecd.org.libezp.lib.lsu.edu/index.aspx?DataSetCode=TABLE_I5\#>; H:

$<$ http://www.caramcdaniel.com/researchpapers>; I: International Labor Organization ILOSTAT Database annual weekly hours actually worked per employed person gender-specific indicator, averaged over the period since year 2000. 
Table 5

The Impact of Taxes and Culture of Leisure on Labor Supply-- Females.

\section{Panel A}

Dependent variable: Labor Force Participation

(1) (2)

The Measure of

Culture is $\begin{array}{cc}\text { Leisure } & \text { People Turn } \\ \text { Important } & \text { Lazy }\end{array}$
(3)

Work Is a

Duty to

Society
(4)

Work Should

Come First
(5)

Generous

Holidays
(6)

LFP in

Origin

Country

Models with the Average Personal Income Tax Rate

\begin{tabular}{|c|c|c|c|c|c|c|}
\hline Average tax & $\begin{array}{l}-0.003 * * \\
(0.001)\end{array}$ & $\begin{array}{l}-0.002 * * \\
(0.001)\end{array}$ & $\begin{array}{l}-0.002 * * \\
(0.001)\end{array}$ & $\begin{array}{l}-0.002 * \\
(0.001)\end{array}$ & $\begin{array}{l}-0.003 * * \\
(0.001)\end{array}$ & $\begin{array}{l}-0.002 * \\
(0.001)\end{array}$ \\
\hline \multirow[t]{2}{*}{ Culture } & $-0.092 * * *$ & -0.010 & 0.002 & 0.021 & $-0.001 * *$ & $0.002 * * *$ \\
\hline & $(0.034)$ & $(0.034)$ & $(0.035)$ & $(0.030)$ & $(0.000)$ & $(0.001)$ \\
\hline \multirow[t]{2}{*}{$\mathrm{N}$} & 3,919 & 3,627 & 3,627 & 3,627 & 3,762 & 2,784 \\
\hline & \multicolumn{6}{|c|}{ Models with the Effective Marginal Tax Rate } \\
\hline \multirow[t]{2}{*}{$\tau$} & -0.003 & -0.003 & -0.003 & -0.003 & $-0.003 *$ & $-0.003 *$ \\
\hline & $(0.002)$ & $(0.002)$ & $(0.002)$ & $(0.002)$ & $(0.002)$ & $(0.002)$ \\
\hline \multirow[t]{2}{*}{ Culture } & $-0.098 * *$ & -0.035 & -0.031 & -0.008 & $-0.001 *$ & $0.002 * *$ \\
\hline & $(0.042)$ & $(0.036)$ & $(0.035)$ & $(0.031)$ & $(0.001)$ & $(0.001)$ \\
\hline \multirow[t]{3}{*}{$\mathrm{N}$} & 2,365 & 2,231 & 2,231 & 2,231 & 2,306 & 1,952 \\
\hline & \multicolumn{6}{|c|}{ 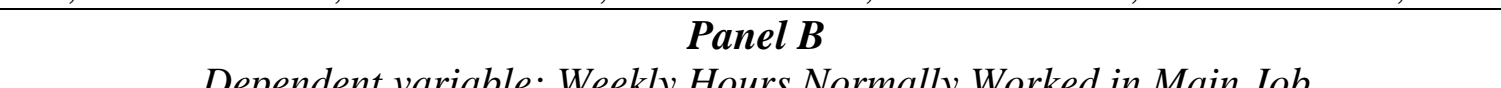 } \\
\hline & $(1)$ & $(2)$ & (3) & $(4)$ & $(5)$ & $(6)$ \\
\hline \multirow[t]{2}{*}{$\begin{array}{l}\text { The Measure of } \\
\text { Culture is } \rightarrow\end{array}$} & $\begin{array}{l}\text { Leisure } \\
\text { Important }\end{array}$ & $\begin{array}{l}\text { People Turn } \\
\text { Lazy }\end{array}$ & $\begin{array}{c}\text { Work Is a } \\
\text { Duty to } \\
\text { Society }\end{array}$ & $\begin{array}{c}\text { Work Should } \\
\text { Come First }\end{array}$ & $\begin{array}{l}\text { Generous } \\
\text { Holidays }\end{array}$ & $\begin{array}{c}\text { Average } \\
\text { Hours in } \\
\text { Origin } \\
\text { Country }\end{array}$ \\
\hline & \multicolumn{6}{|c|}{ Models with the Average Personal Income Tax Rate } \\
\hline \multirow[t]{2}{*}{ Average tax } & $-0.072 *$ & $-0.087 * *$ & $-0.100 * *$ & $-0.098 * *$ & $-0.070 *$ & $-0.116 * *$ \\
\hline & $(0.041)$ & $(0.043)$ & $(0.043)$ & $(0.042)$ & $(0.041)$ & $(0.047)$ \\
\hline \multirow[t]{2}{*}{ culture } & -2.505 & $-3.845 * * *$ & $-2.886^{*}$ & $-2.836 * *$ & 0.014 & 0.175 \\
\hline & $(2.101)$ & $(1.368)$ & $(1.460)$ & $(1.078)$ & $(0.022)$ & $(0.170)$ \\
\hline \multirow[t]{2}{*}{$\mathrm{N}$} & 3,043 & 2,801 & 2,801 & 2,801 & 2,916 & 2,004 \\
\hline & \multicolumn{6}{|c|}{ Models with the Effective Marginal Tax Rate } \\
\hline \multirow[t]{2}{*}{$\tau$} & $-0.149 * *$ & $-0.155^{* *}$ & $-0.160 * *$ & $-0.158 * *$ & $-0.160 * *$ & $-0.210 * * *$ \\
\hline & $(0.067)$ & $(0.068)$ & $(0.069)$ & $(0.068)$ & $(0.067)$ & $(0.068)$ \\
\hline \multirow[t]{2}{*}{ cCulture } & -1.383 & $-2.946 * *$ & -0.935 & $-2.351 *$ & $0.042 *$ & 0.157 \\
\hline & $(1.971)$ & $(1.465)$ & $(1.595)$ & (1.359) & $(0.024)$ & $(0.202)$ \\
\hline $\mathrm{N}$ & 1,785 & 1,675 & 1,675 & 1,675 & 1,742 & 1,467 \\
\hline
\end{tabular}

$\tau$ - The effective marginal tax rate on labor income (Prescott 2004).

avg_all_in100 - Average personal income tax and social security contribution rate on gross labor income for a single person without a dependent (OECD Tax Database Table 5).

Each regression includes the control variables listed in Panels A, C, and D of Table 4.

Standard errors, clustered at the country of origin, are in parentheses. The estimations use sampling weights and include survey year dummies. $* \mathrm{p}<0.1, * * \mathrm{p}<0.05, * * * \mathrm{p}<0.01$. 
Table 6

The Impact of Taxes and Culture of Leisure on Labor Supply--Males.

\section{Panel A}

Dependent variable: Labor Force Participation

\begin{tabular}{|c|c|c|c|c|c|c|}
\hline & (1) & (2) & (3) & (4) & (5) & (6) \\
\hline $\begin{array}{l}\text { The Measure of } \\
\text { Culture is } \rightarrow\end{array}$ & $\begin{array}{l}\text { Leisure } \\
\text { Important }\end{array}$ & $\begin{array}{l}\text { People Turn } \\
\text { Lazy }\end{array}$ & $\begin{array}{l}\text { Work Is a } \\
\text { Duty to } \\
\text { Society }\end{array}$ & $\begin{array}{c}\text { Work Should } \\
\text { Come First }\end{array}$ & $\begin{array}{l}\text { Generous } \\
\text { Holidays }\end{array}$ & $\begin{array}{c}\text { LFP in } \\
\text { Origin } \\
\text { Country }\end{array}$ \\
\hline & \multicolumn{6}{|c|}{ Models with the Average Personal Income Tax Rate } \\
\hline Average tax & $\begin{array}{c}-0.002^{* * *} \\
(0.001)\end{array}$ & $\begin{array}{l}-0.003 * * * \\
(0.001)\end{array}$ & $\begin{array}{c}-0.003 * * \\
(0.001)\end{array}$ & $\begin{array}{c}-0.003 * * \\
(0.001)\end{array}$ & $\begin{array}{c}-0.002 * * \\
(0.001)\end{array}$ & $\begin{array}{c}-0.003^{* * *} \\
(0.001)\end{array}$ \\
\hline Culture & $\begin{array}{l}-0.034 \\
(0.041)\end{array}$ & $\begin{array}{c}0.020 \\
(0.038)\end{array}$ & $\begin{array}{c}0.002 \\
(0.033)\end{array}$ & $\begin{array}{c}0.006 \\
(0.029)\end{array}$ & $\begin{array}{l}-0.000 \\
(0.000)\end{array}$ & $\begin{array}{l}-0.001 \\
(0.001)\end{array}$ \\
\hline $\mathrm{N}$ & 3,423 & 3,172 & 3,172 & 3,172 & 3,299 & 2,371 \\
\hline & \multicolumn{6}{|c|}{ Models with the Effective Marginal Tax Rate } \\
\hline$\tau$ & $\begin{array}{l}-0.002 * \\
(0.001)\end{array}$ & $\begin{array}{c}-0.003^{* *} \\
(0.001)\end{array}$ & $\begin{array}{c}-0.003^{* *} \\
(0.001)\end{array}$ & $\begin{array}{c}-0.003 * * \\
(0.001)\end{array}$ & $\begin{array}{c}-0.002^{*} \\
(0.001)\end{array}$ & $\begin{array}{r}-0.003^{*} \\
(0.002)\end{array}$ \\
\hline Culture & $\begin{array}{l}-0.041 \\
(0.056)\end{array}$ & $\begin{array}{c}0.013 \\
(0.033)\end{array}$ & $\begin{array}{c}0.004 \\
(0.038)\end{array}$ & $\begin{array}{c}0.002 \\
(0.032)\end{array}$ & $\begin{array}{c}0.000 \\
(0.001)\end{array}$ & $\begin{array}{l}-0.001 \\
(0.001)\end{array}$ \\
\hline \multirow[t]{3}{*}{$\mathrm{N}$} & 2,163 & 2,027 & 2,027 & 2,027 & 2,124 & 1,765 \\
\hline & \multicolumn{6}{|c|}{$\begin{array}{c}\text { Panel B } \\
\text { Dependent variable: Weekly Hours Normally Worked in Main Job }\end{array}$} \\
\hline & (1) & (2) & (3) & (4) & (5) & (6) \\
\hline $\begin{array}{l}\text { The Measure of } \\
\text { Culture is } \rightarrow\end{array}$ & $\begin{array}{l}\text { Leisure } \\
\text { Important }\end{array}$ & $\begin{array}{l}\text { People Turn } \\
\text { Lazy }\end{array}$ & $\begin{array}{l}\text { Work Is a } \\
\text { Duty to } \\
\text { Society }\end{array}$ & $\begin{array}{c}\text { Work Should } \\
\text { Come First }\end{array}$ & $\begin{array}{l}\text { Generous } \\
\text { Holidays }\end{array}$ & $\begin{array}{c}\text { Average } \\
\text { Hours in } \\
\text { Origin } \\
\text { Country }\end{array}$ \\
\hline & \multicolumn{6}{|c|}{ Models with the Average Personal Income Tax Rate } \\
\hline Average Tax & $\begin{array}{l}-0.082 * \\
(0.047)\end{array}$ & $\begin{array}{l}-0.079 \\
(0.050)\end{array}$ & $\begin{array}{l}-0.080 \\
(0.049)\end{array}$ & $\begin{array}{l}-0.079 \\
(0.050)\end{array}$ & $\begin{array}{c}-0.097 * * \\
(0.046)\end{array}$ & $\begin{array}{l}-0.111^{*} \\
(0.056)\end{array}$ \\
\hline Culture & $\begin{array}{c}0.305 \\
(1.895)\end{array}$ & $\begin{array}{l}-0.019 \\
(1.483)\end{array}$ & $\begin{array}{l}-0.388 \\
(1.510)\end{array}$ & $\begin{array}{c}0.404 \\
(0.911)\end{array}$ & $\begin{array}{c}0.035 \\
(0.024)\end{array}$ & $\begin{array}{l}0.176^{*} \\
(0.104)\end{array}$ \\
\hline $\mathrm{N}$ & 2,887 & 2,672 & 2,672 & 2,672 & 2,788 & 1,976 \\
\hline & \multicolumn{6}{|c|}{ Models with the Effective Marginal Tax Rate } \\
\hline$\tau$ & $\begin{array}{l}-0.101 \\
(0.064)\end{array}$ & $\begin{array}{l}-0.096 \\
(0.067)\end{array}$ & $\begin{array}{c}-0.095 \\
(0.067)\end{array}$ & $\begin{array}{l}-0.095 \\
(0.067)\end{array}$ & $\begin{array}{c}-0.105^{*} \\
(0.063)\end{array}$ & $\begin{array}{c}-0.158^{* * *} \\
(0.069)\end{array}$ \\
\hline Culture & $\begin{array}{c}0.351 \\
(2.106) \\
\end{array}$ & $\begin{array}{c}0.534 \\
(1.621) \\
\end{array}$ & $\begin{array}{l}-0.191 \\
(1.954) \\
\end{array}$ & $\begin{array}{c}0.007 \\
(1.190) \\
\end{array}$ & $\begin{array}{c}0.037 \\
(0.036) \\
\end{array}$ & $\begin{array}{c}0.230 * * \\
(0.112) \\
\end{array}$ \\
\hline $\mathrm{N}$ & 1,834 & 1,724 & 1,724 & 1,724 & 1,808 & 1,517 \\
\hline
\end{tabular}

$\tau$ - The effective marginal tax rate on labor income (Prescott 2004).

avg_all_in100 - Average personal income tax and social security contribution rate on gross labor income for a single person without a dependent (OECD Tax Database Table 5).

Each regression includes the control variables listed in Panels A, C, and D of Table 4.

Standard errors, clustered at the country of origin, are in parentheses. The estimations use sampling weights and include survey year dummies. $* \mathrm{p}<0.1, * * \mathrm{p}<0.05, * * * \mathrm{p}<0.01$. 
Table 7

Culture of Leisure and Tax Elasticities

\begin{tabular}{llcc}
\hline & Extensive margin & Intensive margin \\
\hline Females & Tax & -0.20 & -0.22 \\
& Culture of Leisure & -0.07 & -0.17 \\
& & -0.17 & -0.10 \\
\hline \multirow{2}{*}{ Males } & Tax & 0.00 & 0.00 \\
& Culture of Leisure &
\end{tabular}

Tax elasticity is calculated using the median estimate of the effective marginal tax rate coefficients reported in Tables 5 and 6 . The elasticity with respect to culture is the median estimate within the relevant panels of Tables 5 and 6.

Table 8

The Impact of Taxes on Labor Supply Models with Country of Origin Fixed Effects.

\begin{tabular}{|c|c|c|c|c|}
\hline & \multicolumn{2}{|c|}{ Female } & \multicolumn{2}{|c|}{ Male } \\
\hline & (1) & (2) & (3) & (4) \\
\hline & LFP & Weekly Hours & LFP & Weekly Hours \\
\hline & \multicolumn{4}{|c|}{ Models with the Average Personal Income Tax Rate } \\
\hline Average tax & $\begin{array}{c}-0.003 * * \\
(0.001)\end{array}$ & $\begin{array}{l}-0.061 \\
(0.048)\end{array}$ & $\begin{array}{c}-0.003 * * \\
(0.001)\end{array}$ & $\begin{array}{c}-0.128 * * * \\
(0.043)\end{array}$ \\
\hline $\mathrm{N}$ & 3,919 & 3,043 & 3,423 & 2,887 \\
\hline \multicolumn{5}{|c|}{ Models with the Effective Marginal Tax Rate } \\
\hline$\tau$ & $\begin{array}{l}-0.004^{*} \\
(0.002)\end{array}$ & $\begin{array}{c}-0.143 * * \\
(0.068)\end{array}$ & $\begin{array}{c}-0.004 * * \\
(0.002)\end{array}$ & $\begin{array}{c}-0.129 * * \\
(0.059)\end{array}$ \\
\hline $\mathrm{N}$ & 2,365 & 1,785 & 2,163 & 1,834 \\
\hline
\end{tabular}

$\tau$ - The effective marginal tax rate on labor income (Prescott 2004).

avg_all_in100 - Average personal income tax and social security contribution rate on gross labor income for a single person without a dependent (OECD Tax Database Table 5).

Each regression includes the control variables listed in Panels A, C, and D of Table 4.

Standard errors, clustered at the country of origin, are in parentheses. The estimations use sampling weights and include survey year and country of origin dummies. ${ }^{*} \mathrm{p}<0.1,{ }^{*} \mathrm{p}<0.05$, *** $\mathrm{p}<0.01$. 
Table 9

The Impact of Culture of Leisure on Labor Supply-- Females

Models with Country of Residence Fixed Effects

\section{Panel A}

Dependent variable: Labor Force Participation

\begin{tabular}{|c|c|c|c|c|c|c|}
\hline & (1) & (2) & (3) & (4) & (5) & (6) \\
\hline $\begin{array}{l}\text { The Measure of } \\
\text { Culture is } \rightarrow\end{array}$ & $\begin{array}{l}\text { Leisure } \\
\text { Important }\end{array}$ & $\begin{array}{l}\text { People Turn } \\
\text { Lazy }\end{array}$ & $\begin{array}{l}\text { Work Is a } \\
\text { Duty to } \\
\text { Society }\end{array}$ & $\begin{array}{l}\text { Work Should } \\
\text { Come First }\end{array}$ & $\begin{array}{l}\text { Generous } \\
\text { Holidays }\end{array}$ & $\begin{array}{l}\text { LFP in } \\
\text { Origin } \\
\text { Country }\end{array}$ \\
\hline & \multicolumn{6}{|c|}{ Models with the Average Personal Income Tax Rate } \\
\hline $\begin{array}{l}\text { Culture } \\
\text { Coefficient }\end{array}$ & $\begin{array}{c}-0.085 * * \\
(0.035)\end{array}$ & $\begin{array}{l}-0.036 \\
(0.029)\end{array}$ & $\begin{array}{l}-0.050^{*} \\
(0.029)\end{array}$ & $\begin{array}{l}-0.002 \\
(0.023)\end{array}$ & $\begin{array}{c}-0.001 * \\
(0.000)\end{array}$ & $\begin{array}{c}0.002 * * \\
(0.001)\end{array}$ \\
\hline \multirow[t]{2}{*}{$\mathrm{N}$} & 3,919 & 3,627 & 3,627 & 3,627 & 3,762 & 2,784 \\
\hline & \multicolumn{6}{|c|}{ Models with the Effective Marginal Tax Rate } \\
\hline $\begin{array}{l}\text { Culture } \\
\text { Coefficient }\end{array}$ & $\begin{array}{l}-0.088^{*} \\
(0.048)\end{array}$ & $\begin{array}{l}-0.053 \\
(0.042)\end{array}$ & $\begin{array}{l}-0.072 * \\
(0.042)\end{array}$ & $\begin{array}{l}-0.019 \\
(0.033)\end{array}$ & $\begin{array}{l}-0.001 \\
(0.001)\end{array}$ & $\begin{array}{c}0.002^{* *} \\
(0.001)\end{array}$ \\
\hline \multirow[t]{3}{*}{$\mathrm{N}$} & 2,365 & 2,231 & 2,231 & 2,231 & 2,306 & 1,952 \\
\hline & \multicolumn{6}{|c|}{$\begin{array}{c}\text { Panel B } \\
\text { Dependent variable: Weekly Hours Normally Worked in Main Job }\end{array}$} \\
\hline & (1) & (2) & (3) & (4) & (5) & (6) \\
\hline $\begin{array}{l}\text { The Measure of } \\
\text { Culture is } \rightarrow\end{array}$ & $\begin{array}{l}\text { Leisure } \\
\text { Important }\end{array}$ & $\begin{array}{l}\text { People Turn } \\
\text { Lazy }\end{array}$ & $\begin{array}{l}\text { Work Is a } \\
\text { Duty to } \\
\text { Society }\end{array}$ & $\begin{array}{l}\text { Work Should } \\
\text { Come First }\end{array}$ & $\begin{array}{l}\text { Generous } \\
\text { Holidays }\end{array}$ & $\begin{array}{c}\text { Average } \\
\text { Hours in } \\
\text { Origin } \\
\text { Country }\end{array}$ \\
\hline & \multicolumn{6}{|c|}{ Models with the Average Personal Income Tax Rate } \\
\hline $\begin{array}{l}\text { Culture } \\
\text { Coefficient }\end{array}$ & $\begin{array}{l}-2.199 \\
(2.101)\end{array}$ & $\begin{array}{l}-2.552^{*} \\
(1.348)\end{array}$ & $\begin{array}{l}-1.146 \\
(1.296)\end{array}$ & $\begin{array}{c}-2.057^{*} \\
(1.066)\end{array}$ & $\begin{array}{c}0.011 \\
(0.022)\end{array}$ & $\begin{array}{c}0.149 \\
(0.192)\end{array}$ \\
\hline \multirow[t]{2}{*}{$\mathrm{N}$} & 3,043 & 2,801 & 2,801 & 2,801 & 2,916 & 2,004 \\
\hline & \multicolumn{6}{|c|}{ Models with the Effective Marginal Tax Rate } \\
\hline $\begin{array}{l}\text { Culture } \\
\text { Coefficient }\end{array}$ & $\begin{array}{l}-1.289 \\
(2.000)\end{array}$ & $\begin{array}{l}-1.991 \\
(1.441)\end{array}$ & $\begin{array}{c}0.532 \\
(1.249)\end{array}$ & $\begin{array}{l}-1.860 \\
(1.229)\end{array}$ & $\begin{array}{c}0.037 \\
(0.029)\end{array}$ & $\begin{array}{c}0.186 \\
(0.213)\end{array}$ \\
\hline $\mathrm{N}$ & 1,785 & 1,675 & 1,675 & 1,675 & 1,742 & 1,467 \\
\hline
\end{tabular}

Each regression includes the control variables listed in Panels A, C, and D of Table 4.

Standard errors, clustered at the country of origin, are in parentheses. The estimations use sampling weights and include survey year and country of destination dummies. $* \mathrm{p}<0.1, * * \mathrm{p}<0.05, * * * \mathrm{p}<0.01$. 
Table 10

The Impact of Culture of Leisure on Labor Supply-- Males

Models with Country of Residence Fixed Effects

\section{Panel A}

Dependent variable: Labor Force Participation

\begin{tabular}{|c|c|c|c|c|c|c|}
\hline & (1) & (2) & (3) & (4) & (5) & (6) \\
\hline $\begin{array}{l}\text { The Measure of } \\
\text { Culture is } \rightarrow\end{array}$ & $\begin{array}{l}\text { Leisure } \\
\text { Important }\end{array}$ & $\begin{array}{l}\text { People Turn } \\
\text { Lazy }\end{array}$ & $\begin{array}{l}\text { Work Is a } \\
\text { Duty to } \\
\text { Society }\end{array}$ & $\begin{array}{c}\text { Work Should } \\
\text { Come First }\end{array}$ & $\begin{array}{l}\text { Generous } \\
\text { Holidays }\end{array}$ & $\begin{array}{c}\text { LFP in } \\
\text { Origin } \\
\text { Country }\end{array}$ \\
\hline & \multicolumn{6}{|c|}{ Models with the Average Personal Income Tax Rate } \\
\hline $\begin{array}{l}\text { Culture } \\
\text { Coefficient }\end{array}$ & $\begin{array}{l}-0.036 \\
(0.045)\end{array}$ & $\begin{array}{c}0.021 \\
(0.038)\end{array}$ & $\begin{array}{c}0.009 \\
(0.032)\end{array}$ & $\begin{array}{c}0.012 \\
(0.030)\end{array}$ & $\begin{array}{l}-0.000 \\
(0.000)\end{array}$ & $\begin{array}{l}-0.001 \\
(0.001)\end{array}$ \\
\hline \multirow[t]{2}{*}{$\mathrm{N}$} & 3,423 & 3,172 & 3,172 & 3,172 & 3,299 & 2,371 \\
\hline & \multicolumn{6}{|c|}{ Models with the Effective Marginal Tax Rate } \\
\hline $\begin{array}{l}\text { Culture } \\
\text { Coefficient }\end{array}$ & $\begin{array}{l}-0.054 \\
(0.056)\end{array}$ & $\begin{array}{c}0.009 \\
(0.038)\end{array}$ & $\begin{array}{l}-0.004 \\
(0.038)\end{array}$ & $\begin{array}{l}-0.005 \\
(0.034)\end{array}$ & $\begin{array}{c}0.000 \\
(0.001)\end{array}$ & $\begin{array}{l}-0.001 \\
(0.001)\end{array}$ \\
\hline \multirow[t]{3}{*}{$\mathrm{N}$} & 2,163 & 2,027 & 2,027 & 2,027 & 2,124 & 1,765 \\
\hline & \multicolumn{6}{|c|}{$\begin{array}{c}\text { Panel B } \\
\text { Dependent variable: Weekly Hours Normally Worked in Main Job }\end{array}$} \\
\hline & (1) & (2) & (3) & (4) & (5) & (6) \\
\hline $\begin{array}{l}\text { The Measure of } \\
\text { Culture is } \rightarrow\end{array}$ & $\begin{array}{l}\text { Leisure } \\
\text { Important }\end{array}$ & $\begin{array}{l}\text { People Turn } \\
\text { Lazy }\end{array}$ & $\begin{array}{l}\text { Work Is a } \\
\text { Duty to } \\
\text { Society }\end{array}$ & $\begin{array}{l}\text { Work Should } \\
\text { Come First }\end{array}$ & $\begin{array}{l}\text { Generous } \\
\text { Holidays }\end{array}$ & $\begin{array}{c}\text { Average } \\
\text { Hours in } \\
\text { Origin } \\
\text { Country }\end{array}$ \\
\hline & \multicolumn{6}{|c|}{ Models with the Average Personal Income Tax Rate } \\
\hline $\begin{array}{l}\text { Culture } \\
\text { Coefficient }\end{array}$ & $\begin{array}{c}0.659 \\
(1.795)\end{array}$ & $\begin{array}{c}0.588 \\
(1.383)\end{array}$ & $\begin{array}{c}0.487 \\
(1.529)\end{array}$ & $\begin{array}{c}1.121 \\
(0.930)\end{array}$ & $\begin{array}{c}0.033 \\
(0.025)\end{array}$ & $\begin{array}{c}0.130 \\
(0.114)\end{array}$ \\
\hline $\mathrm{N}$ & 2,887 & 2,672 & 2,672 & 2,672 & 2,788 & 1,976 \\
\hline & \multicolumn{6}{|c|}{ Models with the Effective Marginal Tax Rate } \\
\hline $\begin{array}{l}\text { Culture } \\
\text { Coefficient }\end{array}$ & $\begin{array}{c}0.519 \\
(2.209)\end{array}$ & $\begin{array}{c}0.720 \\
(1.750)\end{array}$ & $\begin{array}{l}-0.077 \\
(1.783)\end{array}$ & $\begin{array}{r}-0.086 \\
(1.232)\end{array}$ & $\begin{array}{c}0.037 \\
(0.036) \\
\end{array}$ & $\begin{array}{c}0.298^{* *} \\
(0.124)\end{array}$ \\
\hline $\mathrm{N}$ & 1,834 & 1,724 & 1,724 & 1,724 & 1,808 & 1,517 \\
\hline
\end{tabular}

Each regression includes the control variables listed in Panels A, C, and D of Table 4.

Standard errors, clustered at the country of origin, are in parentheses. The estimations use sampling weights and include survey year and country of destination dummies. ${ }^{*} \mathrm{p}<0.1,{ }^{* *} \mathrm{p}<0.05, * * * \mathrm{p}<0.01$. 


\section{References}

Alesina, Alberto, Algan, Yann, Cahuc, Pierre, and Giuliano, Paola. 2015. "Family Values and the Regulation of Labor." Forthcoming in Journal of the European Economic Association.

Alesina, Alberto, and Giuliano, Paola. 2014. "Culture and Institutions." Forthcoming in Journal of Economic Literature.

Alesina, Alberto, and Giuliano, Paola. 2011. "Family Ties and Political Participation.” Journal of the European Economic Association 9, no. 5: 817-839.

Alesina, Alberto, and Giuliano, Paola. 2010. "The Power of the Family." Journal of Economic Growth 15, no. 2: 93-125.

Alesina, Alberto, and Nicola Fuchs-Schündeln. 2007. "Goodbye Lenin (or Not?): The Effect of Communism on People." American Economic Review, 97(4): 1507-1528.

Alesina, Alberto F., Glaeser, Edward L., and Sacerdote, Bruce. 2006. "Work and Leisure in the U.S. and Europe: Why So Different?” NBER Macroeconomic Annual 2005, 20, 1-64.

Algann, Yann and Cahuc, Pierre. 2005. "The Roots of Low European Employment: Family Culture?” NBER International Seminar on Macroeconomics. 65-109.

Barro, Robert and Jong-Wha Lee. "A New Data Set of Educational Attainment in the World, 1950-2010." Journal of Development Economics 104: pp.184-198. Data set BL2013_MF1599_v2.0<http://www.barrolee.com/data/full1.htm>.

Blanchard, Olivier. 2006. "Discussion of Do Taxes Explain European Employment? Indivisible Labor, Human Capital, Lotteries, and Savings, by Lars Ljungqvist and Thomas Sargent." In NBER Macroeconomics Annual, ed. Daron Acemoglu, Kenneth Rogoff and Michael Woodford. Cambridge, Mass.: MIT Press. 225-232.

Blanchard, Olivier. 2004. "The Economic Future of Europe." Journal of Economic Perspectives 18: 3-26.

Cannonier, Colin and Mocan, Naci H. 2012. "Empowering Women Through Education: Evidence from Sierra Leone.” NBER Working Paper No. 18016.

Card, D., DiNardo, J., \& Estes, E. 1998. "The more things change: Immigrants and the children of immigrants in the 1940s, the 1970s, the 1990s.” NBER Working Paper No. 6519.

Chetty, Raj, Adam Guren, Day Manoli, and Andrea Weber. 2011. "Are Micro and Macro Labor Supply Elasticities Consistent? A Review of Evidence on the Intensive and Extensive Margins.” American Economic Review 101(3): 471-75. 
EVS. 2011. European Values Study 1981-2008, Longitudinal Data File. GESIS Data Archive, Cologne, ZA4804 Data File Version 2.0.0, doi:10.4232/1.11005.

Fernández, Raquel. 2013. "Cultural Change as Learning: The Evolution of Female Labor Force Participation over a Century." American Economic Review, 103, no. 1: 472-500.

Fernández, Raquel. 2011. "Does Culture Matter?” Published in Handbook of Social Economics. Editors J. Benhabib, M. O. Jackson, and A. Bisin. Vol. 1A, North-Holland.

Fernández, Raquel. "Culture and Economics." 2008. The New Palgrave Dictionary of Economics. Second Edition. Steven N. Durlauf and Lawrence E. Blume (eds.). Palgrave Macmillan.

Fernández, Raquel. 2007. "Women, Work, and Culture." Alfred Marshall Lecture, Journal of the European Economic Association 5, no. 2-3: 305-332.

Fernández, Raquel and Fogli, Alessandra. 2009. "Culture: An Empirical Investigation of Beliefs, Work and Fertility." American Economic Journal: Macroeconomics 1, no. 1: 146-177.

Fernández, Raquel and Fogli, Alessandra. 2006. "Fertility: The Role of Culture and Family Experience." Journal of the European Economic Association 4, no. 2-3: 552-561.

Giavazzi, Francesco, Petkov, Ivan, and Schiantarelli, Fabio. 2014. "Culture: Persistence and Evolution.” NBER Working Paper No. 20174.

Glaeser, Edward L., Sacerdote, Bruce I. and Scheinkman, Jose A. 2003. "The Social Multiplier." Journal of the European Economic Association, 1, no. 2-3: 345-353.

Giuliano, Paola, and Spilimbergo, Antonio. 2014. "Growing up in a Recession." The Review of Economic Studies 81, no. 2: 787-817.

Hofstede, Geert, and Gert Jan Hofstede. 2005. "Cultures and Organizations: Software of the Mind." New York: McGraw-Hill.

Hofstede, Geert. 2001. "Culture's Consequences: Comparing Values, Behaviors, Institutions and Organizations across Nations." Thousand Oaks, CA: Sage.

Ljunge, Martin. 2014. "Trust Issues: Evidence on the Intergenerational Trust Transmission among Children of Immigrants." Journal of Economic Behavior \& Organization 106: 175-196.

Ljungqvist, Lars, and Sargent, Thomas J. 2006. "Do Taxes Explain European Employment? Indivisible Labor, Human Capital, Lotteries, and Savings." In NBER Macroeconomics Annual, ed. Daron Acemoglu, Kenneth Rogoff and Michael Woodford. Cambridge, Mass.: MIT Press. 181-224.

Luttmer, Erzo F. P, and Singhal, Monica. 2011. "Culture, Context, and the Taste for Redistribution." American Economic Journal: Economic Policy 3, no. 1: 157-179. 
McDaniel, Cara. 2014. Average Tax Series Data, updated December 2014. "More countries, fewer years" file. http://www.caramcdaniel.com/researchpapers

McDaniel, Cara. 2011. "Forces Shaping Hours Worked in the OECD, 1960-2004.” American Economic Journal: Macroeconomics 3, no. 4: 27-52.

Mocan, Naci H. 2013. "Vengeance." The Review of Economics and Statistics 95, no. 3: 969-82.

Ohanian, Lee, Andrea Raffo, and Richard Rogerson. 2008. "Long-Term Changes in Labor Supply and Taxes: Evidence from OECD Countries, 1956-2004." Journal of Monetary Economics, 55(8): 1353-62.

Olovsson, Connie. 2015. “Optimal Taxation with Home Production.” Forthcoming in Journal of Monetary Economics 70, no. 3.

Olovsson, Connie. 2009. "Why Do Europeans Work So Little?” International Economic Review 50, no. 1: 40-61.

Prescott, Edward C. 2004. "Why Do Americans Work So Much More Than Europeans?" Federal Reserve Bank of Minneapolis Quarterly Review 28, no. 1: 2-13.

Roeder, Philip G. 2001. "Ethnolinguistic Fractionalization (ELF) Indices, 1961 and 1985” $<$ http://pages.ucsd.edu/ proeder/elf.htm>.

Rogerson, Richard. 2008. "Structural Transformation and the Deterioration of European Labor Market Outcomes." Journal of Political Economy 116: 235-259

Teorell, Jan, Nicholas Charron, Stefan Dahlberg, Sören Holmberg, Bo Rothstein, Petrus Sundin \& Richard Svensson, 2013. "The Quality of Government Dataset" version qog_std_cs_20dec13 <http://www.qog.pol.gu.se>. 
Appendix Table 1. Measures of Culture of Leisure in the Countries of Origin.

\begin{tabular}{|c|c|c|c|c|c|}
\hline Country & $\begin{array}{l}\text { Leisure Important } \\
\text { (Not al all: } 1 \text { to } \\
\text { Very Important:4) }\end{array}$ & $\begin{array}{l}\text { People Turn } \\
\text { Lazy } \\
\text { (Str. Agree: } 1 \\
\text { to Strongly } \\
\text { Disagree: 5) }\end{array}$ & $\begin{array}{c}\text { Work is a Duty } \\
\text { to Society } \\
\text { (StronlyAgree: } \\
1 \text { to Strongly } \\
\text { Disagree: 5) }\end{array}$ & $\begin{array}{l}\text { Work Should } \\
\text { Come First } \\
\text { (Str. Agree: } 1 \\
\text { to Strongly } \\
\text { Disagree: 5) }\end{array}$ & $\begin{array}{l}\text { Generous Holidays } \\
\text { are Important } \\
\text { (0 to 100-higher } \\
\text { values, stronger } \\
\text { agreement) }\end{array}$ \\
\hline Albania & 2.597 & 1.935 & 2.418 & 1.838 & 53.899 \\
\hline Algeria & 2.953 & & & & 20.515 \\
\hline Argentina & 3.105 & 2.042 & 2.017 & 2.038 & 26.407 \\
\hline Armenia & 3.048 & 2.053 & 2.506 & 2.137 & 38.039 \\
\hline Australia & 3.361 & 2.457 & 2.495 & 3.327 & 17.340 \\
\hline Austria & 3.251 & 2.141 & 2.078 & 2.556 & 20.708 \\
\hline Azerbaijan & 3.066 & 2.209 & 1.965 & 2.437 & 37.003 \\
\hline Bangladesh & 2.777 & 1.942 & 1.434 & 1.663 & 19.339 \\
\hline Belarus & 3.006 & 2.175 & 2.353 & 3.089 & 39.322 \\
\hline Belgium & 3.255 & 2.667 & 2.302 & 3.179 & 28.246 \\
\hline Brazil & 3.297 & 2.163 & 2.131 & 2.395 & 16.107 \\
\hline Bulgaria & 2.955 & 2.036 & 2.121 & 2.219 & 37.069 \\
\hline Burkina Faso & 2.646 & 2.089 & 1.635 & 2.097 & \\
\hline Canada & 3.280 & 2.671 & 2.392 & 3.028 & 26.680 \\
\hline Chile & 3.213 & 2.117 & 2.106 & 2.534 & 26.159 \\
\hline China & 2.571 & 2.039 & 2.084 & 2.234 & 13.701 \\
\hline Colombia & 3.272 & & & & 5.407 \\
\hline Croatia & 3.109 & 2.464 & 2.598 & 2.816 & 33.549 \\
\hline Cyprus & 3.470 & 1.954 & 1.911 & 2.228 & 39.550 \\
\hline Czech Republic & 3.020 & 2.112 & 2.453 & 2.604 & 25.070 \\
\hline Denmark & 3.391 & 2.322 & 2.119 & 2.777 & 18.842 \\
\hline Dominican & 2.957 & & & & 23.426 \\
\hline Egypt & 2.554 & 1.548 & 1.418 & 1.431 & 12.900 \\
\hline Estonia & 2.996 & 2.289 & 2.534 & 2.902 & 30.144 \\
\hline Ethiopia & 3.275 & 1.736 & 1.639 & 1.636 & \\
\hline Finland & 3.343 & 2.521 & 2.422 & 3.090 & 14.920 \\
\hline France & 3.195 & 2.609 & 2.378 & 3.182 & 15.553 \\
\hline Georgia & 3.184 & 2.004 & 2.123 & 1.975 & 23.132 \\
\hline Germany & 3.177 & 2.580 & 2.290 & 2.487 & 24.623 \\
\hline Ghana & 3.337 & 1.848 & 1.535 & 1.782 & \\
\hline Greece & 3.361 & 2.325 & 2.485 & 2.760 & 24.982 \\
\hline Hungary & 3.123 & 1.988 & 2.192 & 2.172 & 34.146 \\
\hline Iceland & 3.225 & 3.594 & 2.564 & 3.247 & 13.723 \\
\hline India & 2.599 & 1.861 & 1.946 & 2.084 & 39.353 \\
\hline Indonesia & 2.817 & 1.975 & 2.507 & 2.003 & 29.980 \\
\hline Iran & 3.038 & & & & 37.480 \\
\hline Iraq & 2.933 & & & & \\
\hline Ireland & 3.271 & 2.563 & 2.380 & 3.012 & 38.054 \\
\hline Israel & & 1.923 & 2.087 & 2.113 & \\
\hline
\end{tabular}




\begin{tabular}{|c|c|c|c|c|c|}
\hline Italy & 3.108 & 2.077 & 2.198 & 2.701 & 23.574 \\
\hline Japan & 3.280 & 2.134 & 2.321 & 3.309 & 62.067 \\
\hline Jordan & 2.840 & 1.588 & 1.402 & 1.636 & 34.757 \\
\hline Latvia & 2.866 & 2.189 & 2.535 & 2.974 & 27.232 \\
\hline Lithuania & 2.914 & 2.512 & 2.701 & 2.706 & 39.831 \\
\hline Luxembourg & 3.278 & 2.460 & 2.073 & 2.875 & 37.592 \\
\hline Macedonia & 3.405 & 2.076 & 2.257 & 2.223 & 33.774 \\
\hline Mali & 2.965 & 1.664 & 1.489 & 1.664 & \\
\hline Malta & 3.370 & 2.277 & 1.942 & 2.777 & 33.231 \\
\hline Mexico & 3.159 & 2.093 & 2.075 & 2.414 & 32.075 \\
\hline Moldova & 2.898 & 2.376 & 2.540 & 2.416 & 55.603 \\
\hline Morocco & 2.916 & 1.794 & 1.494 & 1.565 & 77.658 \\
\hline Netherlands & 3.467 & 2.984 & 2.419 & 3.439 & 36.185 \\
\hline Nigeria & 3.378 & & & & 48.561 \\
\hline Norway & 3.388 & 2.546 & 1.854 & 2.838 & 11.825 \\
\hline Pakistan & 2.246 & & & & \\
\hline Peru & 2.834 & 2.110 & 2.022 & 2.194 & 10.273 \\
\hline Philippines & 2.637 & 2.277 & 2.046 & 1.915 & 9.473 \\
\hline Poland & 3.119 & 2.134 & 2.371 & 2.609 & 31.796 \\
\hline Portugal & 3.041 & 2.160 & 1.910 & 2.647 & 49.582 \\
\hline Romania & 2.975 & 1.848 & 2.162 & 2.071 & 45.499 \\
\hline Russia & 2.968 & 2.139 & 2.662 & 2.686 & 37.635 \\
\hline Rwanda & 3.397 & 1.542 & 1.539 & 1.657 & \\
\hline Saudi Arabia & 2.868 & & & & 48.336 \\
\hline Singapore & 3.065 & 2.184 & 2.257 & 2.648 & 27.180 \\
\hline Slovakia & 3.088 & 1.939 & 2.336 & 2.369 & 28.923 \\
\hline Slovenia & 3.157 & 1.885 & 2.099 & 2.677 & 38.610 \\
\hline South Africa & 3.006 & 2.554 & 2.066 & 2.051 & 25.113 \\
\hline South Korea & 3.064 & 1.710 & 2.321 & 2.940 & 45.696 \\
\hline Spain & 3.221 & 2.318 & 2.382 & 2.725 & 30.524 \\
\hline Sweden & 3.485 & 3.016 & 2.468 & 3.196 & 20.754 \\
\hline Switzerland & 3.346 & 2.662 & 2.267 & 2.869 & 18.506 \\
\hline Thailand & 2.965 & 2.083 & 1.919 & 1.933 & \\
\hline Trinidad and & 3.317 & 2.001 & 1.891 & 2.226 & \\
\hline Turkey & 3.176 & 1.706 & 1.762 & 2.115 & 50.846 \\
\hline Uganda & 3.235 & 2.054 & 2.010 & 1.887 & 46.098 \\
\hline Ukraine & 2.975 & 2.135 & 2.550 & 2.709 & 39.890 \\
\hline United Kingdom & 3.373 & 2.734 & 2.483 & 3.223 & 29.204 \\
\hline United States & 3.297 & 2.566 & 2.502 & 3.111 & 31.466 \\
\hline Uruguay & 3.322 & 2.391 & 2.205 & 2.471 & 38.423 \\
\hline Venezuela & 3.495 & & & & 63.229 \\
\hline Viet Nam & 2.573 & 1.840 & 1.666 & 2.079 & 42.000 \\
\hline Zimbabwe & 2.837 & 2.458 & 2.051 & 1.857 & 38.984 \\
\hline $\mathrm{N}$ & 81 & 73 & 73 & 73 & 72 \\
\hline Mean & 3.091 & 2.194 & 2.149 & 2.459 & 32.047 \\
\hline St. Dev. & 0.257 & 0.360 & 0.330 & 0.507 & 13.641 \\
\hline
\end{tabular}


Appendix Table 2. Descriptive Statistics for the Sample of "Labor Force Participation"

\begin{tabular}{|c|c|c|c|c|c|}
\hline & & \multicolumn{2}{|c|}{ Females } & \multicolumn{2}{|c|}{ Males } \\
\hline Variable & Description (Source) & $\begin{array}{c}\text { avg_all__ } \\
\text { in } 100 \\
\text { sample }\end{array}$ & $\tau$ sample & $\begin{array}{c}\text { avg_all_- } \\
\text { in } 100 \\
\text { sample }\end{array}$ & $\tau$ sample \\
\hline \multicolumn{6}{|c|}{ Panel A: Personal Characteristics } \\
\hline $\begin{array}{l}\text { Labor Force } \\
\text { Participation }\end{array}$ & $\begin{array}{l}==1 \text { if the individual reported being engaged in } \\
\text { any paid work in the last } 7 \text { days or has } \\
\text { "Unemployed and actively looking for a job" } \\
\text { marked as his or her main activity in the last } \\
\text { week, } 0 \text { otherwise }\end{array}$ & $\begin{array}{c}0.677 \\
(0.468)\end{array}$ & $\begin{array}{c}0.670 \\
(0.470)\end{array}$ & $\begin{array}{c}0.772 \\
(0.420)\end{array}$ & $\begin{array}{l}0.762 \\
(0.426)\end{array}$ \\
\hline Age & Age of the respondent & $\begin{array}{c}38.892 \\
(13.758)\end{array}$ & $\begin{array}{c}37.717 \\
(14.016)\end{array}$ & $\begin{array}{c}37.229 \\
(13.881)\end{array}$ & $\begin{array}{c}36.841 \\
(14.131)\end{array}$ \\
\hline Ethnic Minority & $\begin{array}{l}==1 \text { if the respondent belongs to minority } \\
\text { ethnic group in country }\end{array}$ & $\begin{array}{c}0.145 \\
(0.352) \\
\end{array}$ & $\begin{array}{c}0.128 \\
(0.334) \\
\end{array}$ & $\begin{array}{c}0.161 \\
(0.368) \\
\end{array}$ & $\begin{array}{c}0.138 \\
(0.345) \\
\end{array}$ \\
\hline Years of Schooling & $\begin{array}{l}\text { Number of years of full-time education } \\
\text { completed }\end{array}$ & $\begin{array}{l}13.265 \\
(3.498)\end{array}$ & $\begin{array}{l}13.045 \\
(3.713)\end{array}$ & $\begin{array}{l}12.999 \\
(3.489)\end{array}$ & $\begin{array}{l}12.953 \\
(3.554)\end{array}$ \\
\hline Married & $==1$ if the respondent is married, 0 otherwise & $\begin{array}{c}0.512 \\
(0.500)\end{array}$ & $\begin{array}{c}0.467 \\
(0.499)\end{array}$ & $\begin{array}{c}0.470 \\
(0.499)\end{array}$ & $\begin{array}{c}0.442 \\
(0.497)\end{array}$ \\
\hline City & $==1$ if respondent lives in a big city, 0 otherwise & $\begin{array}{c}0.325 \\
(0.468) \\
\end{array}$ & $\begin{array}{c}0.224 \\
(0.417) \\
\end{array}$ & $\begin{array}{c}0.302 \\
(0.459) \\
\end{array}$ & $\begin{array}{c}0.225 \\
(0.418) \\
\end{array}$ \\
\hline \multicolumn{6}{|c|}{ Panel B: Culture of Leisure in Country of Origin } \\
\hline Leisure Important & $\begin{array}{l}\text { Average country response to the question "For } \\
\text { each of the following aspects, indicate how } \\
\text { important it is in your life. Leisure time: } 1 \text { 'Not } \\
\text { at all important' } 2 \text { 'Not very important' } 3 \text { 'Rather } \\
\text { important' } 4 \text { 'Very important"" (A) }\end{array}$ & $\begin{array}{c}3.074 \\
(0.198)\end{array}$ & $\begin{array}{c}3.106 \\
(0.213)\end{array}$ & $\begin{array}{c}3.074 \\
(0.197)\end{array}$ & $\begin{array}{l}3.099 \\
(0.215)\end{array}$ \\
\hline Generous Holidays & $\begin{array}{l}\text { Average country response to the question "Here } \\
\text { are some more aspects of a job that people say } \\
\text { are important. Please look at them and tell me } \\
\text { which ones you personally think are important in } \\
\text { a job. Generous holidays" (A) }\end{array}$ & $\begin{array}{r}34.894 \\
(15.218)\end{array}$ & $\begin{array}{r}31.788 \\
(13.918)\end{array}$ & $\begin{array}{c}35.027 \\
(15.309)\end{array}$ & $\begin{array}{c}32.687 \\
(14.343)\end{array}$ \\
\hline People Turn Lazy & $\begin{array}{l}\text { Average country response to the question "Do } \\
\text { you agree or disagree with the following } \\
\text { statements: People who don't work turn lazy. } 1 \\
\text { 'Strongly agree' } 2 \text { 'Agree' } 3 \text { 'Neither agree nor } \\
\text { disagree' } 4 \text { 'Disagree' } 5 \text { 'Strongly disagree"” (A) }\end{array}$ & $\begin{array}{c}2.172 \\
(0.312)\end{array}$ & $\begin{array}{c}2.208 \\
(0.328)\end{array}$ & $\begin{array}{c}2.170 \\
(0.310)\end{array}$ & $\begin{array}{l}2.199 \\
(0.331)\end{array}$ \\
\hline $\begin{array}{l}\text { Work Is a Duty to } \\
\text { Society }\end{array}$ & $\begin{array}{l}\text { Average country response to the question "Do } \\
\text { you agree or disagree with the following } \\
\text { statements: Work is a duty towards society. } 1 \\
\text { 'Strongly agree' } 2 \text { 'Agree' } 3 \text { 'Neither agree nor } \\
\text { disagree' } 4 \text { 'Disagree' } 5 \text { 'Strongly disagree"" (A) }\end{array}$ & $\begin{array}{c}2.239 \\
(0.335)\end{array}$ & $\begin{array}{c}2.215 \\
(0.284)\end{array}$ & $\begin{array}{l}2.229 \\
(0.337)\end{array}$ & $\begin{array}{r}2.206 \\
(0.289)\end{array}$ \\
\hline
\end{tabular}




\begin{tabular}{|c|c|c|c|c|c|}
\hline \multirow[b]{2}{*}{$\begin{array}{l}\text { Work Should Come } \\
\text { First }\end{array}$} & \multirow{2}{*}{$\begin{array}{l}\text { Average country response to the question "Do } \\
\text { you agree or disagree with the following } \\
\text { statements: Work should always come first, even } \\
\text { if it means less spare time. } 1 \text { 'Strongly agree' } 2 \\
\text { 'Agree' } 3 \text { 'Neither agree nor disagree' } 4 \\
\text { 'Disagree' } 5 \text { 'Strongly disagree"” (A) }\end{array}$} & 2.522 & 2.560 & 2.526 & 2.554 \\
\hline & & $(0.457)$ & $(0.435)$ & $(0.448)$ & $(0.433)$ \\
\hline $\begin{array}{l}\text { Labor Force } \\
\text { Participation }\end{array}$ & $\begin{array}{l}\text { Gender and age group-specific labor force } \\
\text { participation in the country of origin (I) }\end{array}$ & $\begin{array}{c}54.738 \\
(23.289)\end{array}$ & $\begin{array}{c}56.775 \\
(22.968)\end{array}$ & $\begin{array}{c}75.868 \\
(20.770)\end{array}$ & $\begin{array}{l}74.785 \\
(21.109)\end{array}$ \\
\hline \multicolumn{6}{|c|}{ Panel C: Other Country of Origin Characteristics } \\
\hline $\begin{array}{l}\text { Ethnolinguistic } \\
\text { Fragmentation }\end{array}$ & $\begin{array}{l}\text { Roeder's } 1985 \text { Index of the extent of } \\
\text { ethnolinguistic fragmentation in the country (B) }\end{array}$ & $\begin{array}{c}0.285 \\
(0.203)\end{array}$ & $\begin{array}{c}0.265 \\
(0.215)\end{array}$ & $\begin{array}{c}0.284 \\
(0.202)\end{array}$ & $\begin{array}{c}0.269 \\
(0.216)\end{array}$ \\
\hline Democratic & $\begin{array}{l}\text { Number of years in which the country } \\
\text { experienced democracy between } 1930 \text { and } 1995 \\
\text { (C) }\end{array}$ & $\begin{array}{c}22.263 \\
(24.713)\end{array}$ & $\begin{array}{c}28.281 \\
(25.438)\end{array}$ & $\begin{array}{c}23.216 \\
(24.690)\end{array}$ & $\begin{array}{c}28.363 \\
(25.294)\end{array}$ \\
\hline British Legal Origin & $\begin{array}{l}==1 \text { if the legal origin of home country is English } \\
\text { Common Law, } 0 \text { otherwise (C) }\end{array}$ & $\begin{array}{c}0.112 \\
(0.316)\end{array}$ & $\begin{array}{l}0.140 \\
(0.347)\end{array}$ & $\begin{array}{c}0.113 \\
(0.317)\end{array}$ & $\begin{array}{c}0.149 \\
(0.356)\end{array}$ \\
\hline French Legal Origin & $\begin{array}{l}==1 \text { if the legal origin of home country is French } \\
\text { Commercial Code, } 0 \text { otherwise }(C)\end{array}$ & $\begin{array}{c}0.398 \\
(0.490)\end{array}$ & $\begin{array}{c}0.443 \\
(0.497)\end{array}$ & $\begin{array}{c}0.429 \\
(0.495)\end{array}$ & $\begin{array}{c}0.460 \\
(0.499)\end{array}$ \\
\hline $\begin{array}{l}\text { Socialist/Communist } \\
\text { Legal Origin }\end{array}$ & $\begin{array}{l}==1 \text { if the legal origin of home country is } \\
\text { Socialist/Communist Laws, } 0 \text { otherwise }(\mathrm{C})\end{array}$ & $\begin{array}{c}0.371 \\
(0.483)\end{array}$ & $\begin{array}{c}0.260 \\
(0.439)\end{array}$ & $\begin{array}{c}0.341 \\
(0.474)\end{array}$ & $\begin{array}{c}0.247 \\
(0.432)\end{array}$ \\
\hline German Legal Origin & $\begin{array}{l}==1 \text { if the legal origin of home country is } \\
\text { German Commercial Code, } 0 \text { otherwise (C) }\end{array}$ & $\begin{array}{c}0.078 \\
(0.269)\end{array}$ & $\begin{array}{l}0.106 \\
(0.307)\end{array}$ & $\begin{array}{c}0.081 \\
(0.273)\end{array}$ & $\begin{array}{c}0.101 \\
(0.302)\end{array}$ \\
\hline $\begin{array}{l}\text { Scandinavian Legal } \\
\text { Origin }\end{array}$ & $\begin{array}{l}==1 \text { if the legal origin of home country is } \\
\text { Scandinavian Commercial Code, } 0 \text { otherwise (C) }\end{array}$ & $\begin{array}{c}0.041 \\
(0.199)\end{array}$ & $\begin{array}{c}0.052 \\
(0.222)\end{array}$ & $\begin{array}{c}0.037 \\
(0.188)\end{array}$ & $\begin{array}{c}0.043 \\
(0.203)\end{array}$ \\
\hline \multicolumn{6}{|c|}{ Panel D: Country of Destination Characteristics } \\
\hline avg_all_in100 & $\begin{array}{l}\text { Average personal income tax and social security } \\
\text { contribution rate on gross labor income for a } \\
\text { single person without a dependent }(G)\end{array}$ & $\begin{array}{l}25.716 \\
(8.438)\end{array}$ & & $\begin{array}{l}26.471 \\
(8.691)\end{array}$ & \\
\hline$\tau$ & $\begin{array}{l}\text { The effective marginal tax rate calculated using } \\
\text { McDaniel data }(\mathrm{H})\end{array}$ & & $\begin{array}{l}48.758 \\
(9.252) \\
\end{array}$ & & $\begin{array}{l}48.946 \\
(9.210) \\
\end{array}$ \\
\hline Per capita Income & $\begin{array}{l}\text { PPP adjusted GDP per capita in constant } 2011 \\
\text { US\$ (D) }\end{array}$ & $\begin{array}{c}36,426 \\
(11,591)\end{array}$ & $\begin{array}{l}40,024 \\
(8,765)\end{array}$ & $\begin{array}{c}37,656 \\
(13,272)\end{array}$ & $\begin{array}{l}40,052 \\
(8,928)\end{array}$ \\
\hline $\begin{array}{l}\text { Average Country } \\
\text { Education }\end{array}$ & $\begin{array}{l}\text { Average education of individuals aged } 15 \text { and } \\
\text { over in the country (E) }\end{array}$ & $\begin{array}{l}11.570 \\
(0.936)\end{array}$ & $\begin{array}{l}11.336 \\
(0.989)\end{array}$ & $\begin{array}{l}11.518 \\
(0.939)\end{array}$ & $\begin{array}{l}11.355 \\
(0.951)\end{array}$ \\
\hline Population & Country population in millions (D) & $\begin{array}{c}21.262 \\
(26.527)\end{array}$ & $\begin{array}{c}31.014 \\
(29.585)\end{array}$ & $\begin{array}{c}23.090 \\
(28.025)\end{array}$ & $\begin{array}{c}32.974 \\
(30.416)\end{array}$ \\
\hline Individualism & $\begin{array}{l}\text { Hofstede Index of the degree to which } \\
\text { individuals are integrated into groups }(\mathrm{F})\end{array}$ & $\begin{array}{c}63.867 \\
(12.149) \\
\end{array}$ & $\begin{array}{c}68.014 \\
(13.239) \\
\end{array}$ & $\begin{array}{c}64.514 \\
(11.568) \\
\end{array}$ & $\begin{array}{c}68.403 \\
(12.102) \\
\end{array}$ \\
\hline $\begin{array}{l}\text { Ethnolinguistic } \\
\text { Fragmentation }\end{array}$ & $\begin{array}{l}\text { Roeder's } 1985 \text { Index of the extent of } \\
\text { ethnolinguistic fragmentation in the country (B) }\end{array}$ & $\begin{array}{c}0.311 \\
(0.179)\end{array}$ & $\begin{array}{c}0.284 \\
(0.192)\end{array}$ & $\begin{array}{c}0.314 \\
(0.185)\end{array}$ & $\begin{array}{c}0.284 \\
(0.197)\end{array}$ \\
\hline Democratic & $\begin{array}{l}\text { Number of years in which the country } \\
\text { experienced democracy between } 1930 \text { and } 1995 \\
\text { (C) }\end{array}$ & $\begin{array}{l}43.927 \\
(24.111)\end{array}$ & $\begin{array}{c}50.808 \\
(22.013)\end{array}$ & $\begin{array}{c}44.784 \\
(24.202)\end{array}$ & $\begin{array}{c}51.479 \\
(21.374)\end{array}$ \\
\hline British Legal Origin & $\begin{array}{l}==1 \text { if the legal origin of home country is English } \\
\text { Common Law, } 0 \text { otherwise }(\mathrm{C})\end{array}$ & $\begin{array}{c}0.280 \\
(0.449)\end{array}$ & $\begin{array}{c}0.114 \\
(0.318)\end{array}$ & $\begin{array}{c}0.235 \\
(0.424)\end{array}$ & $\begin{array}{c}0.112 \\
(0.315)\end{array}$ \\
\hline
\end{tabular}




\begin{tabular}{|c|c|c|c|c|c|}
\hline French Legal Origin & $\begin{array}{l}==1 \text { if the legal origin of home country is French } \\
\text { Commercial Code, } 0 \text { otherwise }(\mathrm{C})\end{array}$ & $\begin{array}{c}0.220 \\
(0.414)\end{array}$ & $\begin{array}{c}0.318 \\
(0.466)\end{array}$ & $\begin{array}{c}0.248 \\
(0.432)\end{array}$ & $\begin{array}{r}0.320 \\
(0.467)\end{array}$ \\
\hline $\begin{array}{l}\text { Socialist/Communist } \\
\text { Legal Origin }\end{array}$ & $\begin{array}{l}==1 \text { if the legal origin of home country is } \\
\text { Socialist/Communist Laws, } 0 \text { otherwise (C) }\end{array}$ & $\begin{array}{c}0.224 \\
(0.417) \\
\end{array}$ & $\begin{array}{c}0.144 \\
(0.351) \\
\end{array}$ & $\begin{array}{c}0.219 \\
(0.414) \\
\end{array}$ & $\begin{array}{c}0.134 \\
(0.341) \\
\end{array}$ \\
\hline German Legal Origin & $\begin{array}{l}==1 \text { if the legal origin of home country is } \\
\text { German Commercial Code, } 0 \text { otherwise (C) }\end{array}$ & $\begin{array}{c}0.186 \\
(0.389) \\
\end{array}$ & $\begin{array}{c}0.303 \\
(0.459) \\
\end{array}$ & $\begin{array}{c}0.202 \\
(0.401) \\
\end{array}$ & $\begin{array}{c}0.313 \\
(0.464) \\
\end{array}$ \\
\hline $\begin{array}{l}\text { Scandinavian Legal } \\
\text { Origin }\end{array}$ & $\begin{array}{l}==1 \text { if the legal origin of home country is } \\
\text { Scandinavian Commercial Code, } 0 \text { otherwise (C) }\end{array}$ & $\begin{array}{c}0.090 \\
(0.286)\end{array}$ & $\begin{array}{c}0.121 \\
(0.326)\end{array}$ & $\begin{array}{l}0.096 \\
(0.295)\end{array}$ & $\begin{array}{c}0.121 \\
(0.326)\end{array}$ \\
\hline $\mathrm{N}$ & & 3,919 & 2,365 & 3,423 & 2,163 \\
\hline
\end{tabular}

Notes: Personal characteristics variables data come from the ESS survey and cover years from 2004 to 2013. The sample is restricted to second-generation immigrants between 16 and 64 years of age, who do not reporting being permanently disabled or being in military/community service as their main activity in the last 7 days. Survey weights are used. avg_all_in100 sample includes the following countries of destination: Austria, Belgium, Czech Republic, Denmark, Estonia, Finland, France, Germany, Greece, Hungary, Iceland, Ireland, Israel, Italy, Luxembourg, Netherlands, Norway, Poland, Portugal, Slovak Republic, Slovenia, Spain, Sweden, Switzerland, Turkey, and the United Kingdom. $\tau$ sample includes the following countries of destination: Austria, Belgium, Czech Republic, Denmark, Finland, France, Germany, Greece, Hungary, Ireland, Italy, Netherlands, Norway, Poland, Portugal, Slovak Republic, Slovenia, Spain, Sweden, Switzerland, and the United Kingdom.

Depending on specification, measures of culture of leisure are available for the following number of observations: Leisure Important - from to 2,163 to 3,919; Generous Holidays - from 2,124 to 3,762; People Turn Lazy, Work Is a Duty to Society, and Work Should Come First - from 2,027 to 3,627; Country of Origin LFP - from 1,765 to 2,784.

A: World Values Survey and European Values Study data. The original variable Leisure Important had reverse scale; it was recoded so that higher values correspond to "lazier" culture.

B: Philip G. Roeder, 2001. "Ethnolinguistic Fractionalization (ELF) Indices, 1961 and 1985"

<http://pages.ucsd.edu/ proeder/elf.htm>; C: Teorell, Jan, Nicholas Charron, Stefan Dahlberg, Sören Holmberg, Bo Rothstein, Petrus Sundin \& Richard Svensson, 2013. "The Quality of Government Dataset" version qog_std_cs_20dec13 $<$ http://www.qog.pol.gu.se>; D: World Bank's World Development Indicators Database $<$ http://databank. worldbank.org /data/databases.aspx>; E: Barro and Lee data set version BL2013_MF1599_v2.0

<http://www.barrolee.com/data/full1.htm >. The variable is available for the years 2000, 2005, and 2010; the values in between are interpolated; years 2010, 2011, 2012, and 2013 are assigned the 2010 value; F: Hofstede, G. "Cultural Dimensions" $<$ http://geert-hofstede.com/countries.html>. G: OECD Tax Database Table 5

$<$ http://stats.oecd.org.libezp.lib.lsu.edu/index.aspx?DataSetCode=TABLE_I5\#>; H:

$<\mathrm{http} / / /$ www.caramcdaniel.com/researchpapers>; I: International Labor Organization ILOSTAT Database annual genderand-age-group-specific indicator, averaged over the period since year 2002. The following bands were used for the age groups: $15-24,25-54$, and 55-64. 
Appendix Table 3

Models of Table 4 column (1) and Table 5 column (1): Reporting All Coefficients.

\begin{tabular}{|c|c|c|c|c|}
\hline & \multicolumn{2}{|c|}{ Females } & \multicolumn{2}{|c|}{ Males } \\
\hline & (1) & (2) & (3) & (4) \\
\hline & LFP & Weekly Hours & LFP & Weekly Hours \\
\hline \multirow[t]{2}{*}{ Average tax } & $-0.003 * *$ & $-0.072^{*}$ & $-0.002 * *$ & $-0.082^{*}$ \\
\hline & $(0.001)$ & $(0.041)$ & $(0.001)$ & $(0.047)$ \\
\hline \multirow{2}{*}{ Leisure Important } & $-0.092 * * *$ & -2.505 & -0.034 & 0.305 \\
\hline & $(0.034)$ & $(2.101)$ & $(0.041)$ & $(1.895)$ \\
\hline \multicolumn{5}{|l|}{ Personal } \\
\hline \multicolumn{5}{|l|}{ Characteristics } \\
\hline \multirow[t]{2}{*}{ Age } & $0.081 * * *$ & $0.363 * *$ & $0.094 * * *$ & $0.956 * * *$ \\
\hline & $(0.004)$ & $(0.151)$ & $(0.003)$ & $(0.119)$ \\
\hline \multirow[t]{2}{*}{ Age Squared } & $-0.001 * * *$ & $-0.003 *$ & $-0.001 * * *$ & $-0.010 * * *$ \\
\hline & $(0.000)$ & $(0.002)$ & $(0.000)$ & $(0.001)$ \\
\hline \multirow[t]{2}{*}{ Ethnic Minority } & 0.033 & 0.027 & 0.020 & -0.535 \\
\hline & $(0.021)$ & $(0.678)$ & $(0.022)$ & $(0.644)$ \\
\hline \multirow[t]{2}{*}{ Years of Schooling } & $0.011 * * *$ & $0.244 * * *$ & 0.001 & $0.116^{*}$ \\
\hline & $(0.002)$ & $(0.071)$ & $(0.003)$ & $(0.061)$ \\
\hline \multirow[t]{2}{*}{ Married } & $-0.084 * * *$ & $-1.824 * * *$ & $0.033 * *$ & $1.086^{*}$ \\
\hline & $(0.017)$ & $(0.538)$ & $(0.014)$ & $(0.636)$ \\
\hline \multirow[t]{2}{*}{ City } & 0.018 & 0.015 & -0.013 & $-1.650 * * *$ \\
\hline & $(0.017)$ & $(0.542)$ & $(0.019)$ & $(0.419)$ \\
\hline \multirow{2}{*}{\multicolumn{5}{|c|}{$\begin{array}{l}\text { Country of Origin } \\
\text { Characteristics }\end{array}$}} \\
\hline & & & & \\
\hline Ethnolinguistic & 0.016 & -0.388 & 0.022 & -1.943 \\
\hline Fragmentation & $(0.032)$ & $(1.570)$ & $(0.032)$ & (1.559) \\
\hline \multirow{2}{*}{$\begin{array}{l}\text { Fragmentation } \\
\text { Democratic }\end{array}$} & -0.000 & -0.013 & 0.000 & -0.023 \\
\hline & $(0.001)$ & $(0.020)$ & $(0.000)$ & $(0.018)$ \\
\hline \multirow[t]{2}{*}{ French Legal Origin } & 0.040 & 0.584 & 0.030 & 0.744 \\
\hline & $(0.038)$ & $(1.352)$ & $(0.028)$ & (1.269) \\
\hline \multirow{2}{*}{$\begin{array}{l}\text { Socialist/Communist } \\
\text { Legal Origin }\end{array}$} & 0.010 & -0.281 & 0.051 & -0.168 \\
\hline & $(0.046)$ & $(1.741)$ & $(0.036)$ & $(1.508)$ \\
\hline \multirow[t]{2}{*}{ German Legal Origin } & 0.007 & -0.308 & 0.014 & $2.608 * *$ \\
\hline & $(0.036)$ & $(1.237)$ & $(0.022)$ & $(1.301)$ \\
\hline Scandinavian Legal & 0.053 & 1.987 & 0.030 & 2.291 \\
\hline \multirow{2}{*}{\multicolumn{5}{|c|}{$\frac{\text { Origin }}{\text { Country of Destination }}$}} \\
\hline \multirow{2}{*}{\multicolumn{5}{|c|}{$\begin{array}{l}\text { Country of Destination } \\
\text { Characteristics }\end{array}$}} \\
\hline & & & & \\
\hline \multirow[t]{2}{*}{ Per capita Income } & -0.000 & 0.000 & $0.000 * * *$ & $0.000^{*}$ \\
\hline & $(0.000)$ & $(0.000)$ & $(0.000)$ & $(0.000)$ \\
\hline \multirow{2}{*}{$\begin{array}{l}\text { Average Country } \\
\text { Education }\end{array}$} & 0.006 & $-1.256^{* * *}$ & -0.002 & 0.630 \\
\hline & $(0.014)$ & $(0.428)$ & $(0.013)$ & $(0.537)$ \\
\hline \multirow[t]{2}{*}{ Population } & 0.001 & 0.015 & 0.000 & $0.034 * *$ \\
\hline & $(0.001)$ & $(0.018)$ & $(0.000)$ & $(0.016)$ \\
\hline Individualism & -0.001 & -0.070 & $0.002 *$ & -0.048 \\
\hline & $(0.001)$ & $(0.045)$ & $(0.001)$ & $(0.041)$ \\
\hline Ethnolinguistic & $0.142^{*}$ & -1.571 & 0.067 & 3.693 \\
\hline Fragmentation & $(0.073)$ & $(2.372)$ & $(0.051)$ & $(2.651)$ \\
\hline
\end{tabular}




\begin{tabular}{lcccc} 
Democratic & $0.003^{*}$ & -0.059 & -0.001 & $-0.088^{*}$ \\
& $(0.001)$ & $(0.053)$ & $(0.001)$ & $(0.045)$ \\
French Legal Origin & 0.038 & 0.551 & -0.023 & -1.337 \\
& $(0.029)$ & $(1.639)$ & $(0.052)$ & $(1.261)$ \\
Socialist/Communist & $0.152^{* *}$ & $4.596^{*}$ & -0.013 & $-3.899^{*}$ \\
Legal Origin & $(0.066)$ & $(2.654)$ & $(0.056)$ & $(2.204)$ \\
German Legal Origin & $0.118^{* * *}$ & -0.962 & 0.010 & $-2.010^{*}$ \\
& $(0.030)$ & $(1.042)$ & $(0.037)$ & $(1.170)$ \\
Scandinavian Legal & $0.183^{* * *}$ & 1.874 & 0.023 & -1.919 \\
Origin & $(0.042)$ & $(1.291)$ & $(0.029)$ & $(1.303)$ \\
\hline $\mathrm{N}$ & 3,919 & 3,043 & 3,423 & 2,887 \\
\hline avg_all_in100 - Average personal income tax and social security contribution rate on gross labor income for a single \\
person without a dependent $($ OECD Tax Database Table 5). \\
Standard errors clustered at the country of origin are in parentheses. The estimations use sampling weights and include \\
survey year dummies. $* \mathrm{p}<0.1, * * \mathrm{p}<0.05, * * * \mathrm{p}<0.01$.
\end{tabular}

